\title{
Article \\ Activated ERK Signaling Is One of the Major Hub Signals Related to the Acquisition of Radiotherapy-Resistant MDA-MB-231 Breast Cancer Cells
}

\author{
Anjugam Paramanantham ${ }^{1,2}$, Eun Joo Jung ${ }^{1}$, Se-IL Go ${ }^{1}$, Bae Kwon Jeong ${ }^{3}{ }^{\circledR}$, Jin-Myung Jung ${ }^{4}$, \\ Soon Chan Hong ${ }^{5}\left(\mathbb{D}\right.$, Gon Sup Kim ${ }^{2, *}$ (D) and Won Sup Lee ${ }^{1, *(\mathbb{D})}$
}

check for

updates

Citation: Paramanantham, A.; Jung, E.J.; Go, S.-I.; Jeong, B.K.; Jung, J.-M.; Hong, S.C.; Kim, G.S.; Lee, W.S. Activated ERK Signaling Is One of the Major Hub Signals Related to the Acquisition of RadiotherapyResistant MDA-MB-231 Breast Cancer Cells. Int. J. Mol. Sci. 2021, 22, 4940. https://doi.org/10.3390/ijms22094940

Academic Editor: Valentina De Falco

Received: 8 March 2021

Accepted: 30 April 2021

Published: 6 May 2021

Publisher's Note: MDPI stays neutral with regard to jurisdictional claims in published maps and institutional affiliations.

Copyright: (c) 2021 by the authors. Licensee MDPI, Basel, Switzerland. This article is an open access article distributed under the terms and conditions of the Creative Commons Attribution (CC BY) license (https:/ / creativecommons.org/licenses/by/ $4.0 /)$.
1 Departments of Internal Medicine, Institute of Health Sciences and Gyeongsang National University Hospital, Gyeongsang National University College of Medicine, 90 Chilam-dong, Jinju 660-702, Korea; anju.udhay@gmail.com (A.P.); eunjoojung@gnu.ac.kr (E.J.J.); gose1@hanmail.net (S.-I.G.)

2 School of Veterinary and Institute of Life Science, Gyeongsang National University, 900 Gajwadong, Jinju 660-701, Korea

3 Departments of Radiation Oncology, Institute of Health Sciences and Gyeongsang National University Hospital, Gyeongsang National University College of Medicine, 90 Chilam-dong, Jinju 660-702, Korea; blue129j@hanmail.net

4 Departments of Neurosurgery, Institute of Health Sciences and Gyeongsang National University Hospital, Gyeongsang National University College of Medicine, 90 Chilam-dong, Jinju 660-702, Korea; gnuhjjm@gnu.ac.kr

5 Departments of Surgery, Institute of Health Sciences and Gyeongsang National University Hospital, Gyeongsang National University College of Medicine, 90 Chilam-dong, Jinju 660-702, Korea; hongsc@gnu.ac.kr

* Correspondence: gonskim@gnu.ac.kr (G.S.K.); lwshmo@gnu.ac.kr (W.S.L.); Tel.: +82-55-772-2356 (G.S.K.); +82-55-750-8733 (W.S.L.); Fax: +82-55-758-9122 (W.S.L.)

Abstract: Breast cancer is one of the major causes of deaths due to cancer, especially in women. The crucial barrier for breast cancer treatment is resistance to radiation therapy, one of the important local regional therapies. We previously established and characterized radio-resistant MDA-MB-231 breast cancer cells (RT-R-MDA-MB-231 cells) that harbor a high expression of cancer stem cells (CSCs) and the EMT phenotype. In this study, we performed antibody array analysis to identify the hub signaling mechanism for the radiation resistance of RT-R-MDA-MB-231 cells by comparing parental MDA-MB-231 (p-MDA-MB-231) and RT-R-MDA-MB-231 cells. Antibody array analysis unveiled that the MAPK1 protein was the most upregulated protein in RT-R-MDA-MB-231 cells compared to in p-MDA-MB-231 cells. The pathway enrichment analysis also revealed the presence of MAPK1 in almost all enriched pathways. Thus, we used an MEK/ERK inhibitor, PD98059, to block the MEK/ERK pathway and to identify the role of MAPK1 in the radio-resistance of RT-R-MDA-MB-231 cells. MEK/ERK inhibition induced cell death in both p-MDA-MB-231 and RT-R-MDA-MB-231 cells, but the death mechanism for each cell was different; p-MDA-MB-231 cells underwent apoptosis, showing cell shrinkage and PARP-1 cleavage, while RT-R-MDA-MB-231 cells underwent necroptosis, showing mitochondrial dissipation, nuclear swelling, and an increase in the expressions of CypA and AIF. In addition, MEK/ERK inhibition reversed the radio-resistance of RT-R-MDA-MB-231 cells and suppressed the increased expression of CSC markers (CD44 and OCT3/4) and the EMT phenotype ( $\beta$-catenin and $\mathrm{N}$-cadherin/E-cadherin). Taken together, this study suggests that activated ERK signaling is one of the major hub signals related to the radio-resistance of MDA-MB-231 breast cancer cells.

Keywords: radiation-resistant; breast cancer; cell death; ERK; EMT; cancer stem cells (CSCs); PD98059

\section{Introduction}

Breast cancer is one of the major causes of death due to cancer worldwide, especially in women [1]. For breast cancer, many therapies are available such as surgical resection, with 
or without lymph node dissection, radiation, and chemotherapy [2]. Radiation therapy is one of the important local regional therapies for breast cancer treatment [3]. Radiotherapy is applied for most breast cancer patients after surgical resection, but not all patients obtain the same benefits, because some of them suffer from a loco-regional relapse. Radio-resistance is the primary reason for this relapse [4].

Radio-resistance is a process in which the tumor cells or tissues adapt to radio therapyinduced damage [5] and survive irradiation (IR) [6,7]. Radiation can induce a DNA damage response (DDR), which causes cell cycle arrest and the induction of DNA repair, even though the cells with more severe damage from the radiation are induced to undergo apoptosis. The DDR may help the cells survive the IR-induced DNA damage, eventually developing radio-resistance by increasing the DDR rate. In addition, repopulation, hypoxic tumor areas, and cancer stemness are involved in radio-resistance. In DDR to IR and cancer stemness, several signaling pathways are reportedly involved: phosphatidylinositol 3-kinase (PI3K), mitogen-activated protein kinase (MAPK), SIRT pathways, Wnt/ $\beta$-catenin signaling, IL22RA1/STAT3 signaling, and sonic Hedgehog signaling [8]. In addition to the suggested signaling pathways, IR resistance comprises the involvement of a large number of other proteins and their pathways $[9,10]$. Particularly, the radiation-induced ERK activation allows cancer cells to overcome the G2/M phase, which is considered the most vulnerable phase during IR, thereby causing radio-resistance [11-13].

MAPK pathways are key signaling pathways involved in the regulation of normal cell proliferation, survival, and differentiation. Aberrant regulation of the MAPK pathways contributes to the development of cancer; particularly, the extracellular signal-regulated kinase (ERK) is crucially involved in cancer cell proliferation, survival, and metastasis [14]. ERK consists of the p44 ERK1 and p42 ERK2. The ERK is the only known substrate of MEK. MEK1/2 activates ERK through dual tyrosine and threonine phosphorylation [15]. Thus, blocking the ERK pathway has proved to be an efficient mechanism to force cells into a cell death pathway. To potentiate the anti-tumoral effects of various cytotoxic agents, many trials of MEK1/2 pharmacological inhibitors (PD98059 [16], UO0126 [17], and PD184352 [18]) have been used. In addition, recent studies have shown the synergetic effect of the MEK/ERK inhibitor and radiation therapy [19].

Radio-resistant MDA-MB-231 breast cancer cells (RT-R-MDA-MB-231 cells) are reported to have a high proliferation rate, metastatic activity, and adhesion to endothelial cells compared with the parental MDA-MB-231 (p-MDA-MB-231) breast cancer cell line. RT-R-MDA-MB-231 cells harbor increased expressions of cancer stem cell (CSC) markers and the epithelial-mesenchymal transition (EMT) phenotype [8]. We hypothesized that there is a key altered signaling (driving oncogenic signaling) involved in developing RTR-MDA-MB-231 cells. Here, we performed antibody microarray analysis to identify the hub proteins involved in the radio-resistance of RT-R-MDA-MB 231 cells by comparing p-MDA-MB-231 and RT-R-MDA-MB-231 cells because antibody microarray analysis is one of the technologies used for high-throughput protein characterization and discovery [10]. Antibody array analysis is used to measure the expression level of proteins between two different samples [9].

This study was designed to decipher the proteomic differences between p-MDA-MB231 and RT-R-MDA-MB-231 cells, enabling us to corroborate our findings at the molecular level. In addition, we also aimed to investigate the importance of the key altered signaling in the reversal of radio-resistance and the regulation of the CSC and EMT phenotypes that are strongly associated with radio-resistance.

\section{Results}

\subsection{Proteomic Profiling of RT-R-MDA-MB-231 Cell Lines}

To determine the key altered expressions of proteins involved in the radio-resistance of RT-R-MDA-MB 231 cells, we performed and analyzed antibody microarrays to assess the difference in protein expressions between p-MDA-MB-231 and RT-R-MDA-MB-231 cells. The internal normalization ratio (INR) was kept as INR $>1.0$ and INR $<1.0$. With respect 
to this value, we selected around 10 upregulated proteins and 16 downregulated proteins, which are specified in Figure 1A. The highly expressed proteins included mitogen-activated protein kinase 1 (MAPK1), which exhibited about a 2.81-fold increase compared to the p-MDA-MB-231 cells. Next to MAPK1, the highly expressed protein was dual-specificity protein kinase CDC-like kinases (CLK1), which exhibited a 1.32-fold increase.
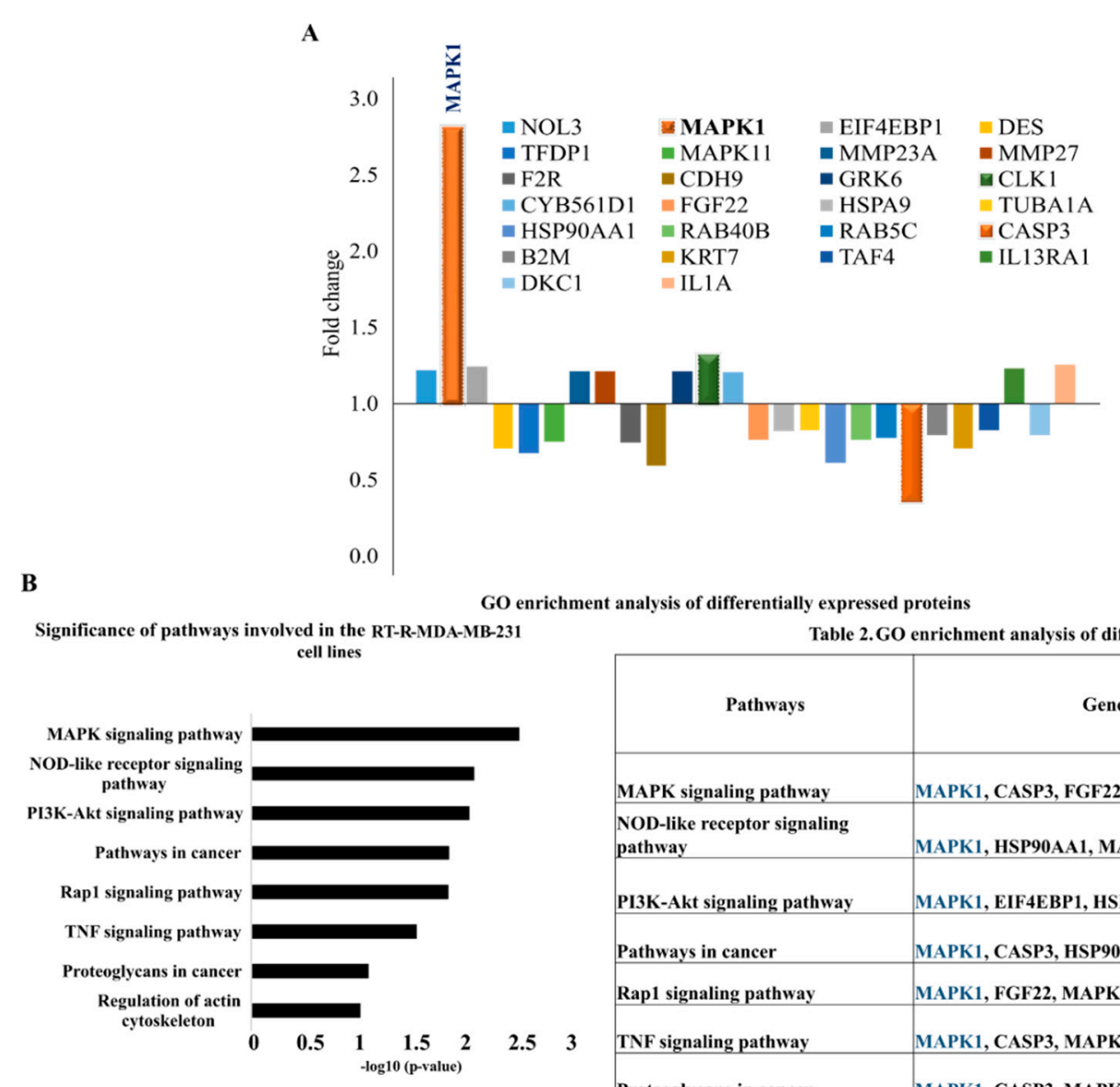

\begin{tabular}{|l|l|l|l|}
\hline \multicolumn{1}{|c|}{ Pathways } & \multicolumn{1}{|c|}{ Genes } & $\begin{array}{c}\text { Genes } \\
\text { involved in } \\
\text { the pathways } \\
(\%)\end{array}$ & $\begin{array}{c}\text { KEGG Pathway } \\
\text { entry }\end{array}$ \\
\hline MAPK signaling pathway & MAPK1, CASP3, FGF22, MAPK11, IL1A & 18 & map04010 \\
\hline $\begin{array}{l}\text { NOD-like receptor signaling } \\
\text { pathway }\end{array}$ & MAPK1, HSP90AA1, MAPK11 & 15 & map04621 \\
\hline PI3K-Akt signaling pathway & MAPK1, EIF4EBP1, HSP90AA1, FGF22, F2R 15 & map04151 \\
\hline Pathways in cancer & MAPK1, CASP3, HSP90AA1, FGF22, F2R & 13 & map05200 \\
\hline Rap1 signaling pathway & MAPK1, FGF22, MAPK11, F2R & 13 & map04015 \\
\hline TNF signaling pathway & MAPK1, CASP3, MAPK11 & 11 & map04668 \\
\hline Proteoglycans in cancer & MAPK1, CASP3, MAPK11 & 8 & map05205 \\
\hline Regulation of actin cytoskeleton & MAPK1, FGF22, F2R & 7 & map04810 \\
\hline
\end{tabular}

Figure 1. Antibody array analysis of radiation-resistant MDA-MB 231 breast cancer cells (RT-R-MDA-MB-231 cells). (A) Graphical representation of differentially expressed proteins with respect to the fold change in RT-R-MDA-MB-231 cells compared to parental MDA-MB-231 (p-MDA-MB-231) cells. (B) Gene ontology enrichment analysis of differentially expressed proteins in RT-R-MDA-MB-231 cells by KEGG analysis. GO enrichment analysis showed that MAPK1 is related to all the suggested signaling pathways involved in the radio-resistance of RT-R-MDA-MB-231 cells (Table 1).

Among the 16 downregulated proteins, caspase 3 was the most downregulated in the RT-R-MDA-MB-231 cells, which is suggested as one of the mechanisms for RT resistance [20]. Figure 1A shows a graphical representation of the proteins concerning the fold change. These findings suggested that the upregulation of MAPK1, CLK1, and FGF22 and the downregulation of caspase 3 might be involved in the acquisition of radio-resistant MDA-MB-231 cells. 
Table 1. GO enrichment analysis of differentially expressed proteins. GO enrichment analysis showed that MAPK1 is related to all the suggested signaling pathways involved in the radio-resistance of RT-R-MDA-MB-231 cells.

\begin{tabular}{cccc}
\hline Pathways & Genes & $\begin{array}{c}\text { Genes Involved in } \\
\text { the Pathways (\%) }\end{array}$ & $\begin{array}{c}\text { KEGG Pathway } \\
\text { Entry }\end{array}$ \\
\hline $\begin{array}{c}\text { MAPK signaling } \\
\text { pathway }\end{array}$ & $\begin{array}{c}\text { MAPK1, CASP3, FGF22, } \\
\text { MAPK11, IL1A }\end{array}$ & 18 & map04010 \\
\hline $\begin{array}{c}\text { NOD-like receptor } \\
\text { signaling pathway }\end{array}$ & $\begin{array}{c}\text { MAPK1, HSP90AA1, } \\
\text { MAPK11 }\end{array}$ & 15 & map04621 \\
\hline $\begin{array}{c}\text { PI3K-Akt signaling } \\
\text { pathway }\end{array}$ & $\begin{array}{c}\text { MAPK1, EIF4EBP1, } \\
\text { HSP90AA1, FGF22, F2R }\end{array}$ & 15 & map04151 \\
\hline $\begin{array}{c}\text { Pathways in cancer } \\
\text { HSP90AA1, FGF22, F2R }\end{array}$ & 13 & map05200 \\
\hline $\begin{array}{c}\text { Rap1 signaling } \\
\text { pathway }\end{array}$ & $\begin{array}{c}\text { MAPK1, FGF22, } \\
\text { MAPK11, F2R }\end{array}$ & 13015 \\
\hline $\begin{array}{c}\text { TNF signaling } \\
\text { pathway }\end{array}$ & $\begin{array}{c}\text { MAPK1, CASP3, } \\
\text { MAPK11 }\end{array}$ & 11 & map04668 \\
\hline $\begin{array}{c}\text { Proteoglycans in } \\
\text { cancer }\end{array}$ & $\begin{array}{c}\text { MAPK1, CASP3, } \\
\text { MAPK11 }\end{array}$ & 8 & map05205 \\
\hline $\begin{array}{c}\text { Regulation of actin } \\
\text { cytoskeleton }\end{array}$ & \begin{tabular}{c} 
MAPK1, FGF22, F2R \\
\hline
\end{tabular} & 7 &
\end{tabular}

\subsection{MAPK1 Is the Most Important Signaling Pathway in Acquiring Radio-Resistant RT-R-MDA-MB-231 Cells}

Gene ontology (GO) enrichment analysis of differentially expressed proteins was carried out with the use of KEGG (Kyoto Encyclopedia of Genes and Genomes) pathway analysis. The KEGG pathway analysis showed that the most significant pathway involved in the RT-R-MDA-MB-231 cells was the MAPK1 signaling pathway (Figure 1B). GO enrichment analysis suggested that MAPK1 is the most important signaling pathway in acquiring radio-resistant RT-R-MDA-MB-231 cells. The differentially expressed proteins were interrogated using the STRING database for the protein-protein interaction network analysis. String analysis of the protein-protein interaction (PPI) network generated an interconnected protein network with a medium confidence level of 0.04 , which created a single module. The PPI network analysis of differentially expressed proteins showed a single module with 15 proteins such as MAPK1, CASP3, FGF22, MAPK11, HSP90AA1, and F2R. They are involved in MAPK signaling, NOD-like receptor signaling, PI3K-Akt signaling, and Pathways in cancer. The highly increased MAPK1 is related to all the suggested pathways. In addition, this module revealed that MAPK1 harbored a direct protein-protein interaction with caspase 3 , which is crucial in inducing programmed cell death type 1 (apoptosis) (Figure 2). These findings support MAPK1 as being one of the important proteins involved in the acquisition of radio-resistant MDA-MB-231 cells.

2.3. ERK Signaling Was Important in the Cell Survival of RT-R-MDA-MB-231 Cells, and the Inhibition of MEK/ERK Signaling Reversed the Radio-Resistance of MDA-MB-231 Cells

To investigate the inhibitory effect of a MEK/ERK inhibitor, PD98059, in RT-R-MDAMB-231 cells, we performed cell viability assays in p-MDA-MB-231 cells and RT-R-MDAMB-231 cells. Morphological analysis (Figure 3A) revealed that the RT-R-MDA-MB-231 cells were highly proliferative compared to the p-MDA-MB-231 cells even in the low dose of PD98059-treated cells (less than $20 \mu \mathrm{M}$ ). However, the proliferation rate of RT-R-MDAMB-231 cells was not higher when they were treated with $20 \mu \mathrm{M}$ of PD98059. The MTT assay showed that the anti-cancer effect of PD98059 was greater on RT-R-MDA-MB-231 cells than on p-MDA-MB-231 cells (Figure 3B). Morphological analysis (Figure 3A) also 
revealed that more cell deaths and cellular collapse were observed in RT-R-MDA-MB-231 cells than in p-MDA-MB-231 cells. In addition, there was a difference in morphology of the cell death between p-MDA-MB-231 cells and RT-R-MDA-MB-231 cells (Figure 3A). These findings suggested that ERK signaling should be important in the cell survival of RT-R-MDA-MB-231 cells, and that the inhibition of ERK signaling might reverse the radio-resistance of MDA-MB-231 cells.

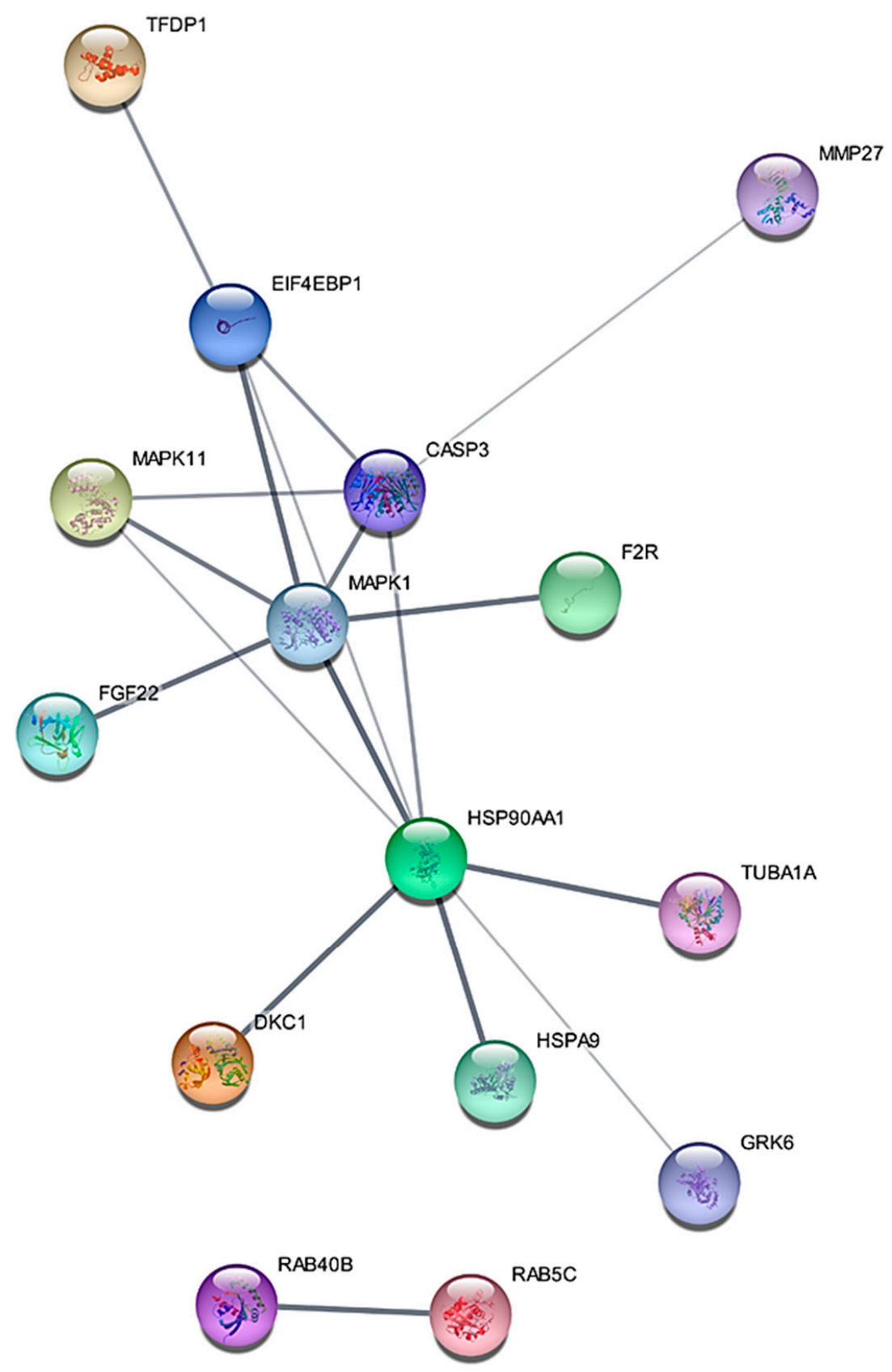

Figure 2. STRING (Cytoscape 3.6) analysis showed the protein-protein interaction (PPI) network of 13 proteins such as MAPK1, CASP3, FGF22, MAPK11, HSP90AA1, and F2R. They are involved in MAPK signaling, NOD-like receptor signaling, PI3K-Akt signaling, and Pathways in cancer in RT-RMDA-MB-231 cells. The lines connecting the proteins depict "known" or "predicted" interactions. The thickness of the line corresponds to the strength of the interaction between the proteins. A total of 30 edges (protein-protein relationships) were discovered from 22 expected edges. 
A

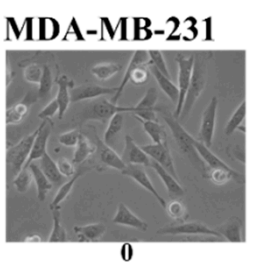

RT-R-MDA-MB-231

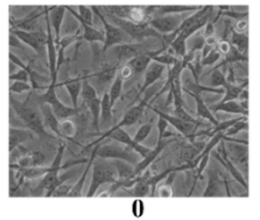

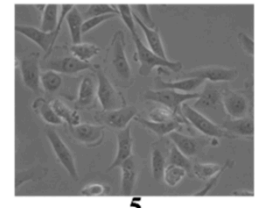

5 PD98059 $(\mu \mathrm{M})$

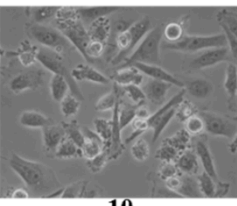

10

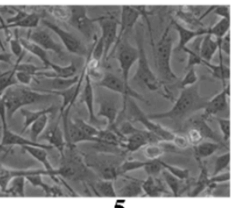

5

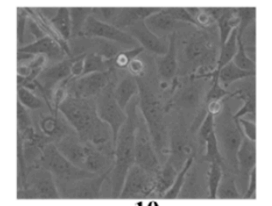

10

PD98059 $(\mu \mathrm{M})$

B
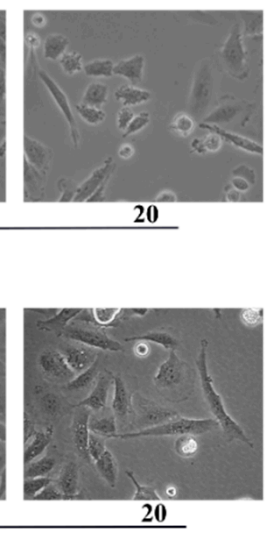

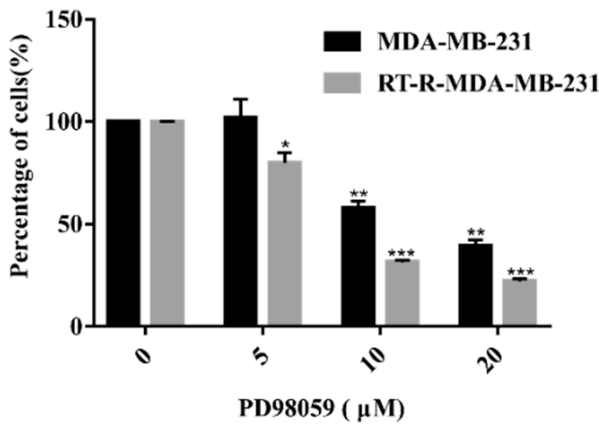

$\operatorname{PD} 98059(\mu \mathrm{M})$

Figure 3. A MEK/ERK inhibitor (PD98059) inhibited the proliferation and promoted cell death in both p-MDA-MB-231 and RT-R-MDA-MB-231 cells. (A) p-MDA-MB-231 and RT-R-MDA-MB-231 cells were treated with PD98059 at the given concentrations. Morphological analyses were performed under a light microscope at $48 \mathrm{~h}$. MEK/ERK inhibition resulted in significant morphological changes in both p-MDA-MB-231 and RT-R-MDA-MB-231 cells with a loss of cell integrity, as well as the reduction in cell population compared to the untreated intact cells (magnification, $\times 200$; scale bar, $200 \mu \mathrm{m}$ ). (B) Cell viability was determined via MTT assay. The graph represents the $\%$ of viable cells after MEK/ERK inhibition. The values are expressed as mean \pm standard deviation (SD) $(n=5)\left({ }^{*} p<0.05\right.$ vs. each control; ${ }^{* *} p<0.01$ vs. each control; ${ }^{* * *} p<0.005$ vs. each control).

\subsection{Inhibition of ERK Signaling Reversed the Radio-Resistance of RT-R-MDA-MB-231 Cells}

To explore the radio-sensitivity of both p-MDA-MB-231 and RT-R-MDA-MB-231 cells, we performed a colony formation assay. This revealed that RT-R-MDA-MB-231 cells were resistant to radiation (RT) until 4 Gy, whereas p-MDA-MB-231 cells were sensitive to RT treatment (Figure 4A,B). The colony number of RT-R-MDA-MB-231 cells was higher than that of p-MDA-MB-231 cells, which suggested that the RT-R-MDA-MB-231 cells were highly proliferative compared to p-MDA-MB-231 cells (Figure 4A,B). To investigate the correlation between activated ERK signaling and radio-resistance in RT-R-MDA-MB-231 cells, we performed an ERK inhibition test with a colony formation assay. As shown in Figure 4C,D, the inhibition of MEK/ERK (at $20 \mu \mathrm{M}$ of PD98059) reversed the radioresistance of RT-R-MDA-MB-231 cells. These findings support the importance of activated ERK signaling for the radio-resistance of RT-R-MDA-MB-231 cells.

\subsection{Inhibition of ERK Signaling-Induced Necroptosis of RT-R-MDA-MB-231 Cells While It Induced the Apoptosis of $p-M D A-M B-231$ Cells}

In Figure 3A, we found differences in the morphology between p-MDA-MB-231 cells and RT-R-MDA-MB-231 cells after ERK inhibition. To elucidate the differences in cell morphology between the two types of cells, we performed mitochondria staining, Mayer's hematoxylin staining for the cell structure, and DAPI for the nucleus. MitoTracker ${ }^{\circledR}$ Red staining is used to show the live time status of mitochondria [21]. The staining revealed that, with the treatment of the MEK/ERK inhibitor, mitochondrial fragmentation was seen in RT-R-MDA-MB-231 cells at the $24 \mathrm{~h}$-inhibition of ERK signaling (Figure 5A). With the inhibition of ERK signaling, RT-R-MDA-MB-231 cells showed more fragmentation and swollen mitochondria than p-MDA-MB-231 cells did, suggesting that ERK inhibition contributes to the mitochondrial fission in RT-R-MDA-MB-231 cells. Mayer's hematoxylin staining revealed that $24 \mathrm{~h}-\mathrm{MEK} / \mathrm{ERK}$ inhibition induced the cell swelling of nuclei and cytoplasm in RT-R-MDA-MB-231, while it induced the shrinkage of nuclei in the p-MDAMB-231 cell (Figure 5B). These results were also confirmed with DAPI staining. The DAPI staining revealed a high level of nuclear swelling in RT-R-MDA-MB-231 cells treated with the MEK/ERK inhibitor, and it revealed nuclear fragmentation in p-MDA-MB-231 cells 
(Figure 5C). These results suggest that the ERK inhibition promotes cell death in both p-MDA-MB-231 and RT-R-MDA-MB-231 cells, but that the mechanisms for the cell death of the two cells were different.

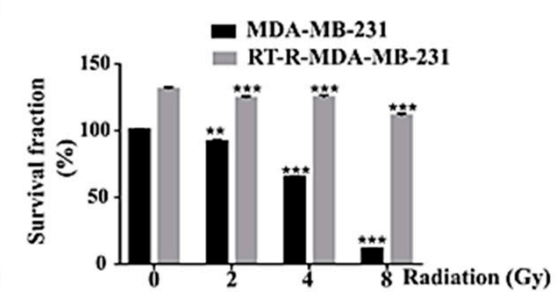

c

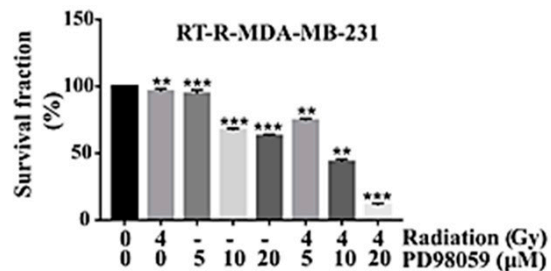

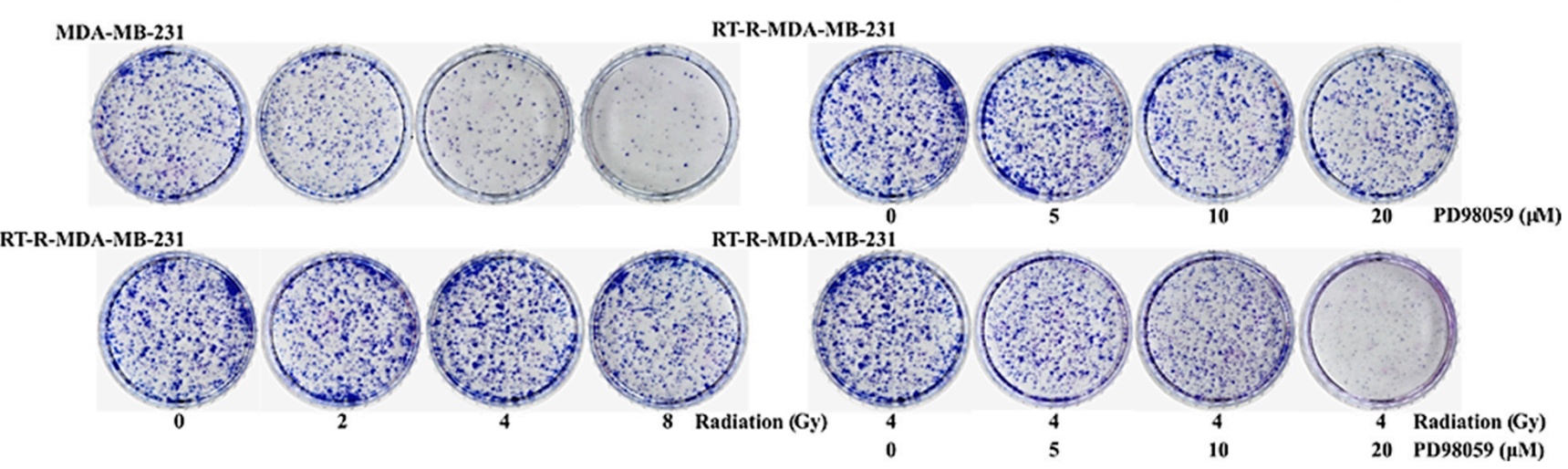

Figure 4. Clonogenic assay for effects of ERK inhibition on radio-resistance of RT-R-MDA-MB-231 cells. (A) Graphical representation of survival fraction of p-MDA-MB-231 cells and RT-R-MDA-MB-231 cells in \% with the number of colonies after RT treatment. (B) Colony formation assay of RT-R-MDA-MB-231 cells and MDA-MB-231 cells. The cells were irradiated with different doses of RT (as indicated), they were grown for 2 weeks, and they were then stained with $0.1 \%$ Giemsa stain. Images were captured by a CCD (charge-coupled device) camera and the figures are representative of three independent experiments. (C) Graphical representation of RT-R-MDA-MB-231 cells survival fraction in \% with the number of colonies after MEK/ERK inhibition with and without IR. (D) Colony formation assay of RT-R-MDA-MB-231 cells after MEK/ERK inhibition with and without IR and recorded as specified in (B). The values are represented as mean \pm standard deviation (SD) $(n=5) .{ }^{* *} p<0.01 ;{ }^{* * *} p<0.005$.

2.6. ERK Inhibition Induced Caspase Activation and PARP-1 Cleavages in p-MDA-MB-231 Cells, While It Did Increase the Expression of Cyclophilin A (CypA) and AIF in RT-R-MDA-MB-231 Cells

To molecularly confirm the difference in cell death between p-MDA-MB-231 and RT-R-MDA-MB-231 cells, we performed Western blot analysis. Figure 6 demonstrates that, in MDA-MB-231 cells, ERK inhibition induced the cleavage PARP-1 and caspase-3, which is a hallmark for caspase-dependent apoptosis, but that, in the RT-R-MDA-MB-231 cells, ERK inhibition induced AIF (apoptosis-inducing factor), which positively regulates the CypA protein, which is considered a biomarker of necroptosis [22]. These findings support ERK inhibition inducing the apoptosis of p-MDA-MB-231 and the necroptosis of RT-R-MDA-MB-231 cells. 


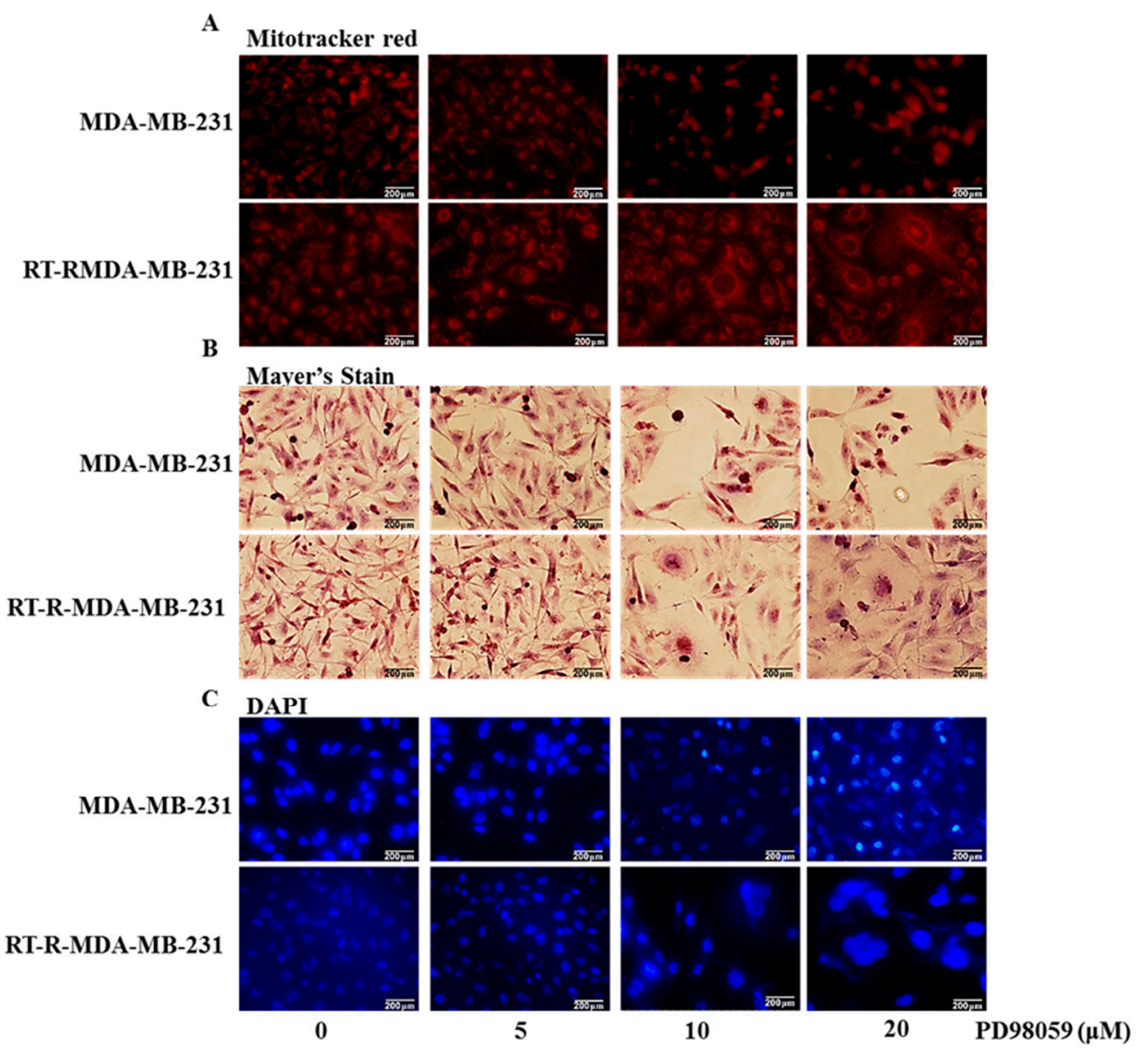

Figure 5. The difference in cell morphology between p-MDA-MB-231 and RT-R-MDA-MB-231 cells during ERK inhibition. Cells were seeded in 12-well plates with a $1 \times 10^{5}$ cell/well density treated with the indicated concentrations of the MEK/ERK inhibitor (PD98059) for $24 \mathrm{~h}$. (A) Mitochondrial morphology was analyzed with a fluorescent microscope after staining with MitoTracker (red). (B) Light microscopy of hematoxylin-stained cells showed the whole cell morphology of the MEK/ERK inhibitorinduced cell death. (C) Nuclear morphology analysis of the MEK/ERK inhibitor-induced cell death with DAPI staining. Results were confirmed by three independent experiments.

2.7. ERK Inhibition Reduced the Expression of Cancer Stem Cell (CSC) Markers (CD44 and Oct $\frac{3}{4}$ ) and the EMT Phenotype, Which Is Closely Related to the Radio-Resistance of RT-R-MDA-MB-231 Cells

It was reported that CSC markers and EMT phenotypes were highly expressed in RT-RMDA-MB-231 cells compared to the p-MDA-MB-231 cells, and that their high expression was closely related to radio-resistance [8]. Here, we assessed the effect of ERK inhibition on the expression of CSC markers and the EMT phenotype on both MDA-MB-231 and RT-R-MDAMB-231 cells. As previously reported, Western blot analysis revealed that RT-R-MDA-MB-231 cells showed a higher expression of CSC markers (CD44 and Oct 3/4) and EMT markers (Ncadherin and $\beta$-catenin) compared to the p-MDA-MB-231 cells (Figure 7A,B). ERK inhibition significantly suppressed the expression of CSC markers and the EMT phenotype in both p-MDA-MB-231 and RT-R-MDA-MB-231 cells (Figure 7A,B). In addition, the ERK inhibition more prominently suppressed the EMT phenotype of RT-R-MDA-MB-231 cells than p-MDAMB-231 cells. These findings indicated that the ERK inhibition clearly suppressed the high expression of CSC markers and the EMT phenotype of RT-R-MDA-MB-231 cells that are reportedly associated with radio-resistance [5]. 
A

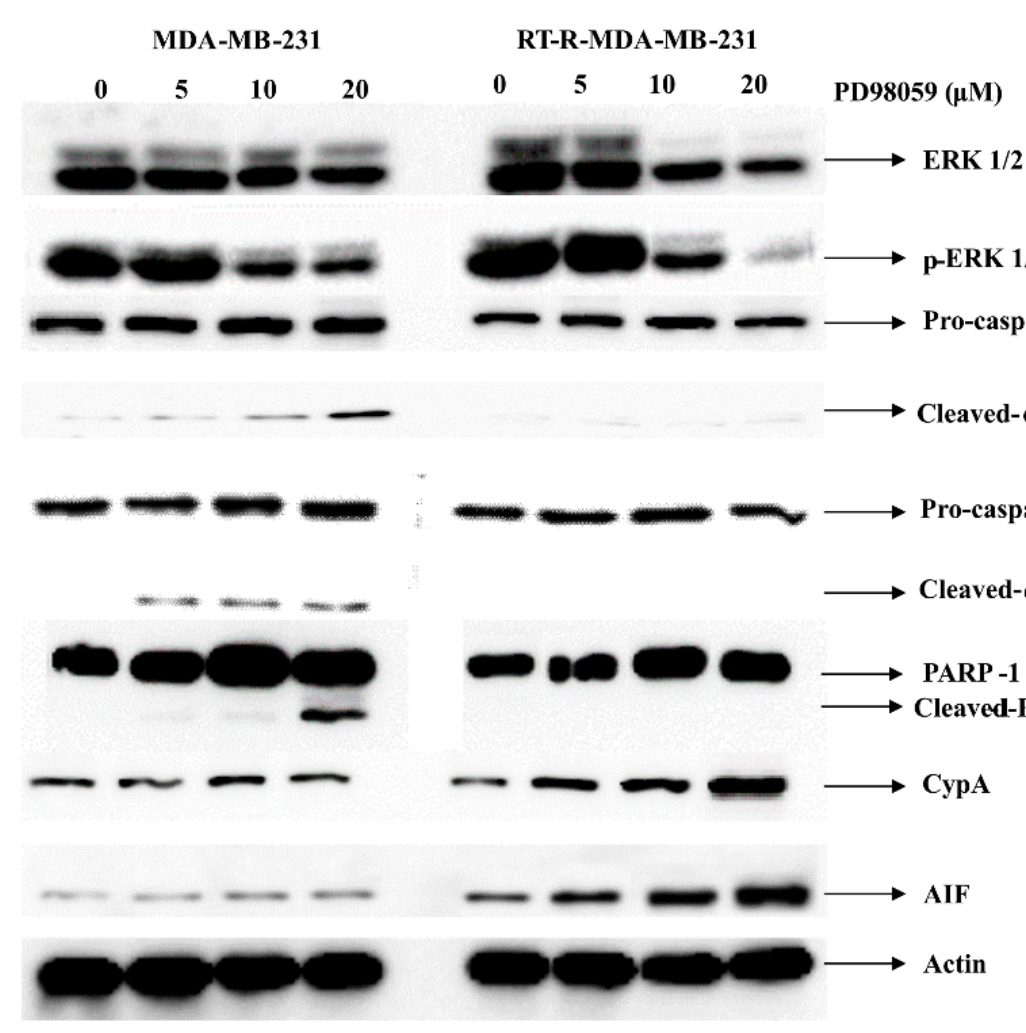

B
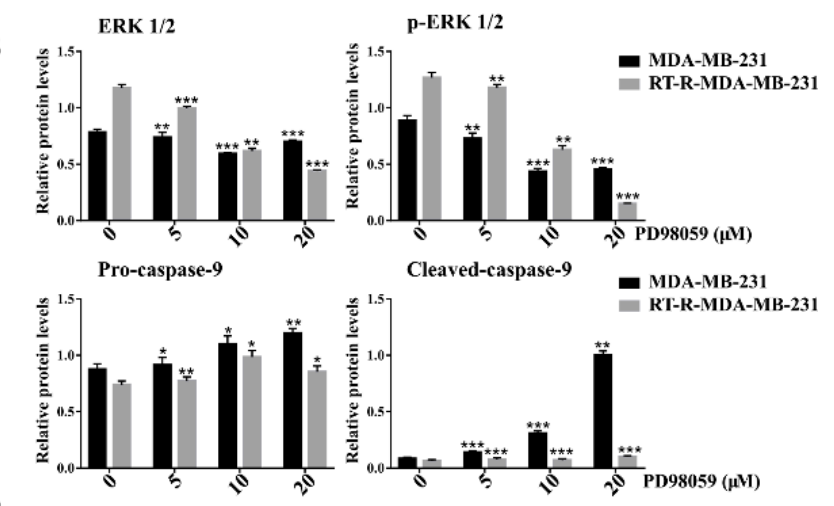

Pro-caspase-3

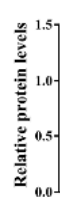
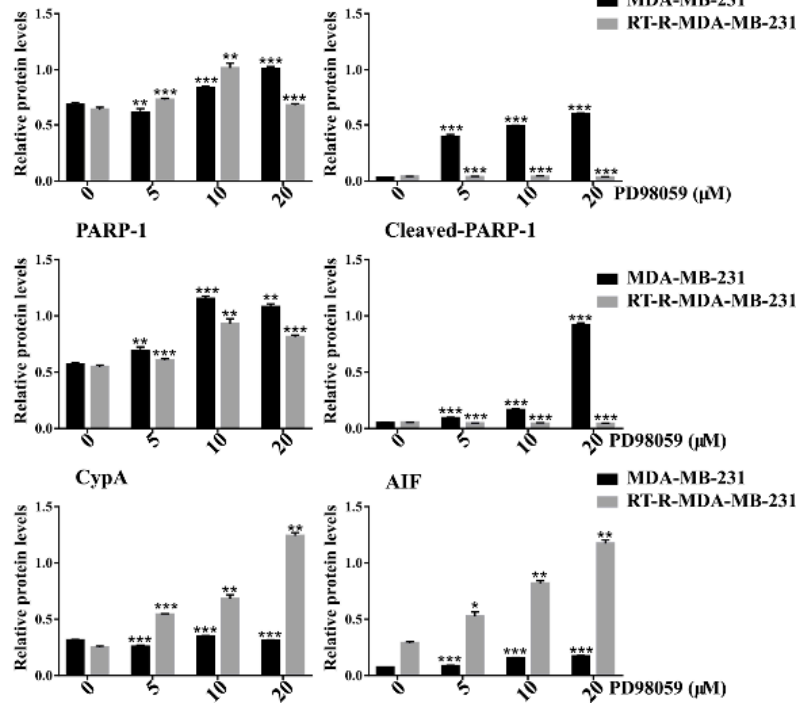

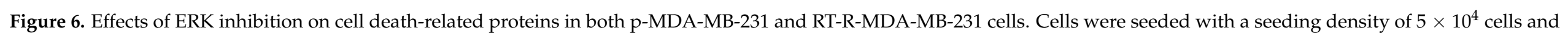

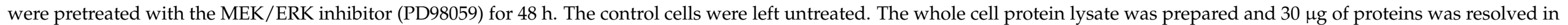

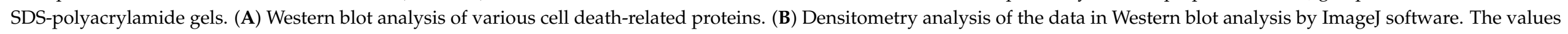
were normalized against $\beta$-actin, and they are represented as mean \pm standard deviation (SD) $(n=3) .{ }^{* *} p<0.01$; ${ }^{* * *} p<0.005$ vs. the control group. 
A

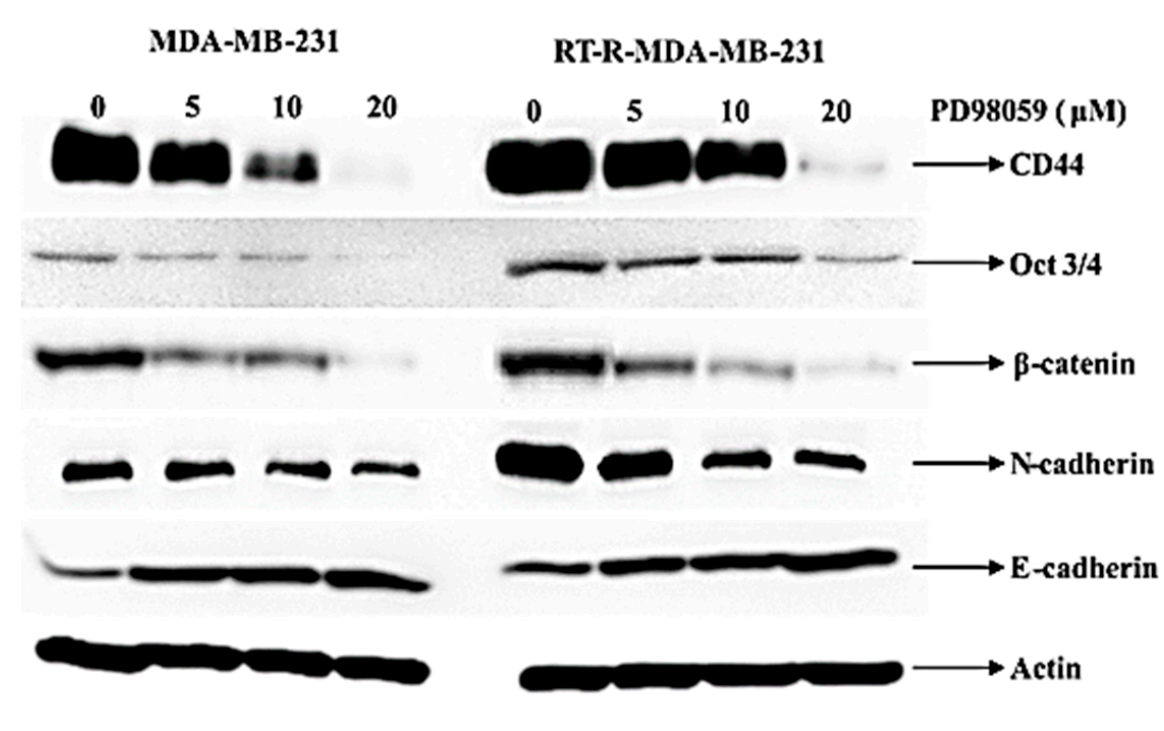

B

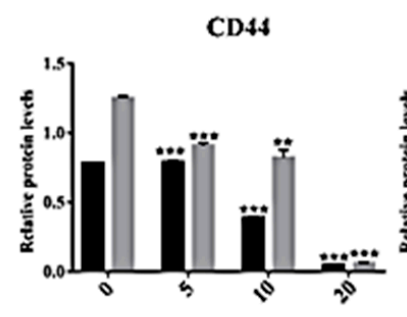

B-Catenin

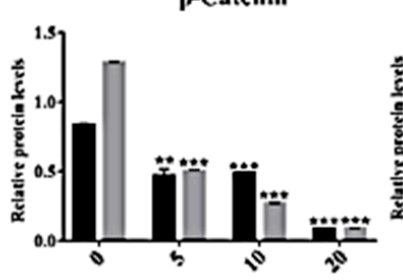

N-cadherin

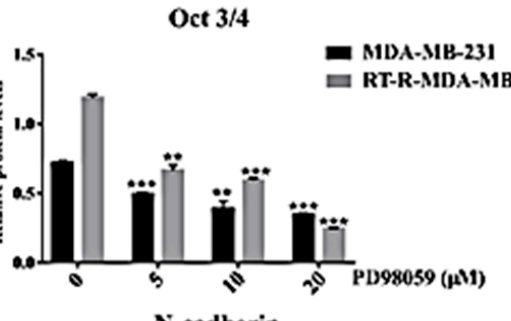

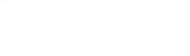

日 RT-R-MDA-NB-231
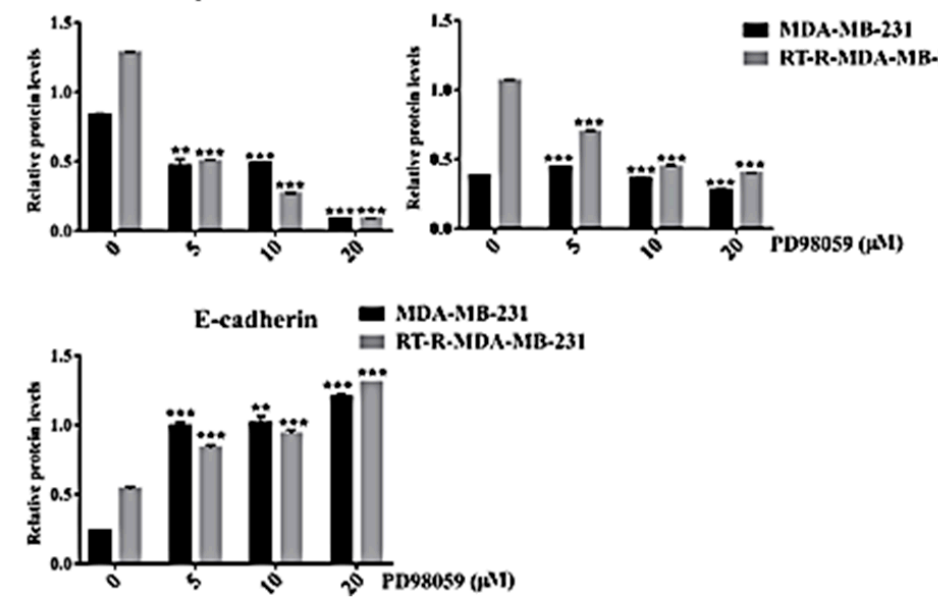

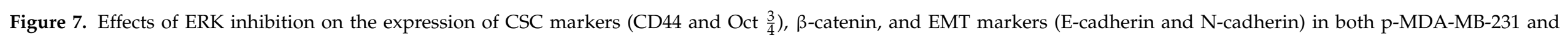

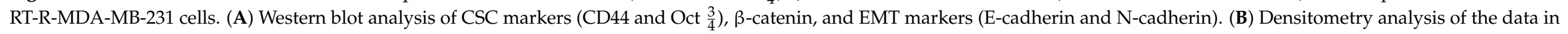

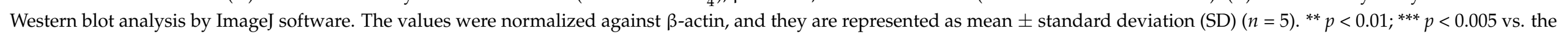
control group. 


\section{Material and Methods}

\subsection{Protein Array Analysis}

The total proteins of p-MDA-MB-231 and RT-R-MDA-MB-231 cells were isolated with a radioimmunoprecipitation assay (RIPA) buffer, which contained $0.1 \%$ NP- 40 and $0.1 \%$ sodium dodecyl sulfate in phosphate-buffered saline (PBS) containing a protease inhibitor cocktail (Sigma Aldrich, St. Louis, MO, USA). The expression profiling of proteins was analyzed by a Signaling Explorer Antibody Array (Ebiogen, Seoul, Korea).

\subsection{Bioinformatics Analysis}

The obtained proteins from the antibody array analysis were further submitted to DAVID (The Database for Annotation, Visualization, and Integrated Discovery). DAVID is an online tool that provides a biological understanding between two or more data sets of genes, and it can also be used to determine gene ontology (GO) in terms of biological processes and cellular processes. To determine the pathways involved in the identified genes, KEGG (Kyoto Encyclopedia of Genes and Genomes) (https:/ /www.genome.jp/ $\mathrm{kegg} /$ pathway.html, accessed on 20 October 2018) was employed. The selected genes were investigated for potential protein-protein interactions using STRING (Search Tool for the Retrieval of Interacting Genes) database version: 10.5 (https:/ / string-db.org, accessed on 19 February 2021). For the display of protein interactions, selected proteins were uploaded into the STRING database and assessed using Cytoscape Software version Cytoscape_v3.7.1 (https: / / www.cytoscape.org, accessed on 19 February 2021). To access the interaction of the experimental data and to provide unambiguous comprehensive coverage, the online tool string was used.

\subsection{Cell Culture}

RT-MDA-MB-231 cells were established as previously described [8]. Briefly, MDAMB-231 cells were fractionated with X-ray irradiation until a final dose of 50 Gy was reached. p-MDA-MB-231 and RT-MDA-MB-231 cells were cultured in RPMI-1450 medium supplemented with $10 \%$ heat-inactivated FBS and $1 \%$ penicillin/streptomycin. The cells were maintained at $37^{\circ} \mathrm{C}$ in a $5 \% \mathrm{CO}_{2}$ incubator. The cells were grown with $80 \%$ confluence and were treated with a MEK/ERK inhibitor (PD98059) dissolved in DMSO or DMSO alone.

\subsection{Cell Viability Assay}

We used a calorimetric assay, MTT (3-(4,5-dimethylthiazol-2-yl)-2,5-diphenyltetrazolium bromide), to analyze the cell viability. The cells were seeded in 24-well plates with a confluence of $1 \times 10^{5}$ cells/well, they were treated with the MEK/ERK inhibitor, and they were maintained for 24 and $48 \mathrm{~h}$ at $37{ }^{\circ} \mathrm{C}$ in a $5 \% \mathrm{CO}_{2}$ incubator. After incubation, $50 \mu \mathrm{L}$ of MTT ( $0.5 \mathrm{mg}$ in $1 \times$ PBS) was added to each well and incubated for about $2 \mathrm{~h}$ at $37{ }^{\circ} \mathrm{C}$ in a $5 \% \mathrm{CO}_{2}$ incubator. The media were removed and the formazan crystals that formed in the live cells were dissolved with the $500 \mu \mathrm{L}$ of DMSO. The solubilized formazan crystals were transferred to 96-well plates and the absorbance was read by an enzyme-linked immunosorbent assay (ELISA) reader at $540 \mathrm{~nm}$. The cell viability was quantified in percentage, while vehicle-treated control cells were set at 100\%.

\subsection{Colony Formation Assay}

P-MDA-MB-231 or RT-R MDA-MB-231 cells $\left(1 \times 10^{3}\right.$ cells/well $)$ were seeded in sixwell plates, treated with the indicated doses of the MEK/ERK inhibitor, and maintained at $37^{\circ} \mathrm{C}$ in a $5 \% \mathrm{CO}_{2}$ incubator. The cells were irradiated with a given concentration, and the media were discarded after $24 \mathrm{~h}$ and replaced with fresh complete media every $2-3$ days. After 14 days, the medium was discarded and the cells were washed with $1 \times$ PBS thrice. The colonies were fixed with absolute methanol for $10 \mathrm{~min}$, stained with Giemsa staining solution, and then maintained at room temperature. The number of colonies was counted using ImageJ software. 


\subsection{Cytochemical Staining Methods}

\subsubsection{Mitotracker Red Analysis}

For mitochondrial morphology analysis, Mitotracker Red dye was used. The cells were seeded with a confluence of $1 \times 10^{5}$ cell/well in 12-well plates, they were treated with the MEK/ERK inhibitor for $24 \mathrm{~h}$, and they were washed with $1 \times$ PBS and then stained with $0.5 \mu \mathrm{L}$ of Mitrotracker red in $500 \mu \mathrm{L}$ of $1 \times$ PBS. The cells were incubated for $30 \mathrm{~min}$ in a $5 \% \mathrm{CO}_{2}$ incubator at $37^{\circ} \mathrm{C}$. After incubation, the cells were viewed under a fluorescent microscope for the analysis of the live mitochondrial status after the treatment of a MEK/ERK inhibitor.

\subsubsection{Hematoxylin Staining}

The cells were seeded in 12-well plates with a confluence of $1 \times 10^{5}$ cells/well and were grown for $24 \mathrm{~h}$ with the MEK/ERK inhibitor at $37^{\circ} \mathrm{C}$ in a $\mathrm{CO}_{2}$ incubator. After incubation, the cells were washed with $1 \times$ PBS and then fixed with $4 \%$ para-formaldehyde overnight. The fixed cells were washed thrice with $1 \times$ PBS for about $5 \mathrm{~min}$ per wash, they were stained with $200 \mu \mathrm{L}$ of Mayer's hematoxylin staining solution, and they were incubated for $20 \mathrm{~min}$ in the dark at room temperature. Then, the cells were washed thoroughly with $1 \times$ PBS, followed by $1 \mathrm{~mL}$ of $90 \%$ glycerol, and they were observed under a phase-contrast microscope.

\subsubsection{DAPI (4',6-diamidino-2-phenylindole) Staining}

For the nuclear morphological changes, DAPI staining was performed. The cells were seeded in 12-well plates at a density of $1 \times 10^{5}$ cells/well with the treatment of the MEK/ERK inhibitor for about $24 \mathrm{~h}$, they were washed with $1 \times$ PBS, and they were fixed overnight with $4 \%$ formaldehyde. After fixation, the cells were washed with $1 \times$ PBS thrice for about $5 \mathrm{~min}$ per wash. DAPI solution $(0.5 \mu \mathrm{L})$ was added to the $500 \mu \mathrm{L}$ of $1 \times$ PBS, which was incubated for $30 \mathrm{~min}$ at $37^{\circ} \mathrm{C}$ with a $5 \% \mathrm{CO}_{2}$ incubator. After incubation, the cells were washed with $1 \times$ PBS and were fixed with $90 \%$ glycerol in $1 \times$ PBS. The cells were viewed under a fluorescent microscope (Leica Microsystems GmbH, Wetzlar, Germany).

\subsection{Western Blot Analysis}

P-MDA-MB-231 and RT-MDA-MB-231 cells were seeded in $100 \mathrm{~mm}$ plates with a cell density of $2 \times 10^{6}$ cells/plate. The cells were treated with the MEK/ERK inhibitor or DMSO as a vehicle control and were maintained for $48 \mathrm{~h}$ at $37^{\circ} \mathrm{C}$ with a $5 \% \mathrm{CO}_{2}$ incubator. After $48 \mathrm{~h}$, the cells were harvested and transferred to $15 \mathrm{~mL}$ falcon tubes, and they were centrifuged for $5 \mathrm{~min}$ at $2000 \mathrm{rpm}$. The supernatant was discarded, and the tubes were centrifuged again to remove the residual supernatant. After complete removal of the supernatant, $500 \mu \mathrm{L}$ of the $2 \mathrm{X}$ sample buffer containing $100 \mathrm{mM}$ of Tris- $\mathrm{Cl}(\mathrm{pH} 6.8), 4 \%$ $(w / v)$ sodium dodecyl sulphate (SDS), $0.2 \%(w / v)$ bromophenol blue, and $200 \mathrm{mM}$ of dithiothreitol was added. The protein lysates were collected in $1.5 \mathrm{~mL}$ Eppendorf tubes and kept at $100{ }^{\circ} \mathrm{C}$ for $10 \mathrm{~min}$. The protein concentration was determined by the Bradford assay. In addition, $30 \mu \mathrm{g}$ of the proteins was resolved in 8-12\% SDS-PAGE and was transferred to a polyvinylidene difluoride membrane. After transfer, the membranes were blocked with $3 \%$ skimmed milk in Tris-buffered saline containing 1\% Tween 20 (TBST) buffer for $30 \mathrm{~min}$ at room temperature, and they were incubated at $4{ }^{\circ} \mathrm{C}$ overnight with antibodies against actin (A5441, 1:10,000, Sigma-Aldrich, St. Louis, MO, USA), ERK (SC-94, 1:2000, Santa Cruz Biotechnology, Dallas, TX, USA), p-ERK (SC-7383, 1:2000, Santa Cruz Biotechnology), CypA (SC-134310, 1:2000, Santa Cruz Biotechnology), pro-caspase 9 (SC-56076, 1:2000, Santa Cruz Biotechnology), pro-caspase 3 (SC-7272, 1:2000, Santa Cruz Biotechnology), AIF (SC-55519, 1:1000, Santa Cruz Biotechnology), PARP-1 (SC-8007, 1:2000, Santa Cruz Biotechnology), CD44 (ab51037, 1:2000, Abcam, Cambridge, UK), $\beta$-catenin (SC-7199, 1:2000, Santa Cruz Biotechnology), Oct 3/4 (SC-5279, 1:2000, Santa Cruz Biotechnology), E-cadherin (ab1416, 1:2000, Abcam), and N-cadherin (ab76011, 1:2000, Abcam). After overnight incubation in primary antibodies, the membranes were washed with TBST buffer thrice for about 
10 min per wash. Then, the membranes were incubated in horseradish peroxidase (HRP)conjugated secondary antibody for $2 \mathrm{~h}$ at room temperature with 1:2000 dilution. The membranes were later washed with TBST buffer three times $(10 \mathrm{~min} /$ wash $)$ and were developed with ECL (electrochemiluminescence) solutions (Bio-Rad Laboratory, Hercules, CA, USA).

\subsection{Statistical Analysis}

All experiments were performed at least in triplicate, and all analyses were performed with the use of GraphPad Prism 7 software (GraphPad Software, San Diego, CA, USA). One-way ANOVA followed by the Newman-Keuls post hoc test was performed to compare various treatment groups. The data were presented as mean \pm standard deviation (SD). A $p$-value $<0.05$ was considered statistically significant.

\section{Discussion}

Radiation therapy is one of the common and essential parts of breast cancer treatment. Around half of the cancer patients go through radiation therapy at some point in their treatment [23]. Ionizing radiation (IR) induces DNA damage through oxidative stress. The free $\mathrm{OH}$ radicals are capable of promoting single-stranded and double-stranded DNA breaks (SSB and DSB, respectively), which, in turn, triggers cell death [24]. Thus, cells develop IR resistance by counteracting the four ' $R$ 's,' which is DNA damage by DNA repair, redistribution, repopulation, and reoxygenation through the activation of various pathways [25]. Several studies have described the role of irradiation in breast cancer pathways and the involvement of several proteins in the development of resistance against radiation, which we have listed in Table 2. Only a small number of studies have investigated mechanisms of acquired radio-resistance through the generation of radio-resistant cell lines, which tend to focus on a single specific pathway. Thus, it is paramount to focus on the signaling mechanism through the generation of the radio-resistant breast cancer cell line.

This study was designed to find the hub signaling involved in the RT resistance of RT-R-MDA-MB-231 cells and to investigate the importance of the hub signaling in the reversal of radio-resistance and the regulation of the CSC and EMT phenotype that is highly associated with radio-resistance. We found that ERK signaling was highly activated in RT-R-MDA-MB-231 cells compared to in p-MDA-MB-231 cells and that ERK signaling was essential for the survival of both p-MDA-MB-231 and RT-R-MDA-MB-231 cells. In addition, the RT resistance of RT-R-MDA-MB-231 cells was reversed by the inhibition of ERK signaling (Figure 4). Furthermore, we demonstrated that the activated ERK signaling was associated with cancer stemness and EMT phenotype (Figure 7). Considering all these findings, we can conclude that activated ERK signaling is one of the major hub signaling related to the acquisition of radio-resistant MDA-MB-231 cells. 
Table 2. List of studies involving radiation resistance and sensitivity in MDA-MB-231 cells or TNBC, and their possible mechanisms behind it. The reports were mainly categorized into three parts as follows: (i) specific signaling pathways involved in radio-resistant breast cancer cells, (ii) signaling pathways involved in radio-sensitivity, (iii) altered expression of gene/proteins involved in radio-resistant breast cancer cells. (iv) Studies that did not fall into any of the three above categories. Abbreviations: IFIT2-interferon-induced protein with tetratricopeptide repeats 2, TRIB3-tribbles homolog 3, ESM-1—endothelial cell-specific molecule-1, DLX2—vertebrate distal-less homeobox 2.

\begin{tabular}{|c|c|c|c|c|}
\hline No. & Author & Key Findings & Year & References \\
\hline \multicolumn{5}{|c|}{ (i) Specific signaling pathways involved in radio-resistant breast cancer cells } \\
\hline 1. & Gray et al. & $\begin{array}{c}\text { The radiation-resistant ER+ breast cancer cell line (MCF-7, } \\
\text { ZR-751) showed increased migration and invasion compared } \\
\text { to the radiation-resistant ER- breast cancer cell line } \\
\text { (MDA-MB-231). ER+ cells also showed a shift from ER to } \\
\text { EGFR signaling pathways with increased MAPK and } \\
\text { PI3K activity. }\end{array}$ & 2019 & [26] \\
\hline 2. & Ediriweera et al. & $\begin{array}{l}\text { A phenolic lipid, 10-Gingerol, promotes apoptosis in } \\
\text { radiation-resistant MDA-MB-231 cells through the PI3K/Akt } \\
\text { signaling pathway. }\end{array}$ & 2020 & [27] \\
\hline 3. & Jin et al. & $\begin{array}{l}\text { The overexpression of ESM- } 1 \text { plays a critical role in } \\
\text { radiation-resistant MDA-MB- } 231 \text { cells through the regulation } \\
\text { of PDK, PKC, and ERK } 1 / 2 \text { pathways, and the subsequent } \\
\text { activation of transcription factors HIF- } 1 \alpha, \text { NF- } \mathrm{K} \text {, and STAT-3 } \\
\text { to regulate adhesion molecules, MMPs, and VEGF. }\end{array}$ & 2020 & [28] \\
\hline 4. & lu et al. & $\begin{array}{l}\text { The Wnt/ } \beta \text {-catenin signaling pathway plays an important role } \\
\text { in the development of radioresistance and Niclosamide, an } \\
\text { FDA-approved anthelmintic drug that induces radiosensitivity } \\
\text { in radiation-resistant MDA-MB-231 via inhibiting STAT3 } \\
\text { and Bcl-2. }\end{array}$ & 2018 & [29] \\
\hline 5. & Bravatà et al. & $\begin{array}{l}\text { Gene expression profiles of the MDA-MB-231 radiation cell } \\
\text { fraction show increased TNF signaling, Phagosome, NF-kappa } \\
\text { B signaling, Jak-STAT signaling, and PI3K-Akt signaling. }\end{array}$ & 2019 & [30] \\
\hline 6. & Choi et al. & $\begin{array}{l}\text { DLX2 expression with irradiation incidence causes the } \\
\text { increase in the EMT process and CSCs population through the } \\
\text { Smad } 2 / 3 \text { signaling pathway in MDA-MB-231 and A549 cells. }\end{array}$ & 2016 & [31] \\
\hline
\end{tabular}

(ii) Signaling pathways involved in radio sensitivity of MDA-MB-231 cells

Niclosamide, an antihelminthic drug, inhibited the

7. Yin et al.

Wnt/ $\beta$-catenin signaling pathway and increased the radiation sensitivity to triple-negative breast cancer (TNBC) cells

(MDA-MB-231, MDA-MB-468, and Hs578T cells).

8. $\quad$ Lin et al.

COX-2 upregulation promotes radioresistance in

alteration of apoptosis and metastasis.

9. KO et al. cell proliferation, cell adhesion, EMT process, and increased
stem cell population.

\section{9. $\quad$ KO et al.}

10. Koh et al.
Baicalein reduced the stem cell-like properties and metastasis in radiation-resistant MDA-MB-231 cells through the upregulation of IFIT2. 
Table 2. Cont.

\begin{tabular}{|c|c|c|c|c|}
\hline No. & Author & Key Findings & Year & References \\
\hline \multicolumn{5}{|c|}{ (iii) Altered expression of gene/proteins involved in radio-resistant MDA-MB-231 cells. } \\
\hline 11. & Lammering et al. & $\begin{array}{l}\text { Irradiation increased the expression of the EGFR protein in } \\
\text { MDA-MB-231 xenograft tumors. }\end{array}$ & 2004 & [35] \\
\hline 12 & Kim et al. & $\begin{array}{l}\text { Proteomic analysis revealed single and the fraction of } \\
\text { radiation increased cathepsin D (CTSD), gelsolin (GSN), } \\
\text { argininosuccinate synthase } 1 \text { (ASS1), and C-type mannose } \\
\text { receptor } 2 \text { (MRC2) in MDA-MB-231 cells. }\end{array}$ & 2015 & [36] \\
\hline 13. & Miao et al. & $\begin{array}{c}\text { Radiation-resistant MDA-MB-231 and MCF-7 cells showed an } \\
\text { altered expression of several members of the HSP70 and } \\
\text { HSP40, subfamilies of HSPs, and an increased level of HSPB8, } \\
\text { a target of NF- } \mathrm{kB} \text { that could be responsible for the } \\
\text { development of radioresistance. }\end{array}$ & 2019 & [37] \\
\hline 14. & Lee et al. & $\begin{array}{l}\text { Increased expression of TRIB3 in radiation-resistant } \\
\text { MDA-MB-231 cells causes the resistance and knockdown of } \\
\text { TRIB3 sensitized toward radiation. }\end{array}$ & 2019 & [38] \\
\hline 15. & HOU et al. & $\begin{array}{l}\text { Microarray analysis of radiation-resistant MDA-MB-231 cells } \\
\text { showed increased cell adhesion and EMT factors. }\end{array}$ & 2019 & [39] \\
\hline 16. & Yang et al. & $\begin{array}{l}\text { Overexpression of a small RNA molecule miR-634 decreases } \\
\text { the survival rate of radiation-resistant MCF-7 and } \\
\text { MDA-MB-231 cells by direct interaction with STAT3. }\end{array}$ & 2020 & [40] \\
\hline \multicolumn{5}{|c|}{ (iv) Studies that did not fall into any of the three above categories. } \\
\hline 17. & Li et al. & $\begin{array}{l}\text { A small molecule, ABT-787, induces radiosensitivity in } \\
\text { radiation-resistant MDA-MB-231 by targeting Bcl-2 and Bcl-xL. }\end{array}$ & 2012 & [41] \\
\hline 18. & Nguyen et al. & $\begin{array}{c}\text { A phytochemical phenethyl isothiocyanate reduces the CSC } \\
\text { population in radiation-resistant MDA-MB-231 cells through } \\
\text { upregulating ROS levels and targeting Metadherin at the } \\
\text { post-transcriptional levels. }\end{array}$ & 2020 & [42] \\
\hline 19. & Oommen and Prise & $\begin{array}{l}\text { A novel benzylidene lactam compound, KNK437, inhibits } \\
\text { HIF-1 } \alpha, \text { HSF1, and AKT in hypoxia-induced MDA-MB-231 } \\
\text { and T98G cells, which, in turn, induces radiosensitivity. }\end{array}$ & 2012 & [43] \\
\hline 20. & Kuger et al. & $\begin{array}{l}\text { PI3K/mTOR inhibitor NVP-BEZ235 showed a synergistic } \\
\text { effect with irradiation (IR) in MCF-7 and MDA-MB-231 cells. }\end{array}$ & 2014 & {$[44]$} \\
\hline 21. & Holler et al. & $\begin{array}{l}\text { The molecular targeting of Akt by Akt inhibitor MK2206 or the } \\
\text { knockdown of Akt1 led to a rapamycin-induced } \\
\text { radiosensitization of SK-MES-1, HTB-182, or MDA-MB-231 } \\
\text { cells by increasing DNA-double-stranded breaks. }\end{array}$ & 2016 & {$[45]$} \\
\hline 22. & Chen et al. & $\begin{array}{l}\text { The estrogen receptor mediates the radiosensitivity of } \\
\text { TNBC cells. }\end{array}$ & 2017 & {$[46]$} \\
\hline 23. & Liu et al. & $\begin{array}{l}\text { Hypoxia due to a high cell density downregulated the EGFR } \\
\text { expression and increased the sensitivity to ionizing radiation } \\
\text { in MCF-7 and MDA-MB-231 cells. }\end{array}$ & 2018 & [47] \\
\hline 24. & Arnold et al. & $\begin{array}{l}\text { STAT3 inhibition combined with radiation reduces the cellular } \\
\text { plasticity in MDA-MB-231 and SUM159PT cells. }\end{array}$ & 2019 & [48] \\
\hline
\end{tabular}

Before concluding, we should discuss some questions. The first question would be whether activated ERK signaling is the main mechanism for the radio-resistance of MDAMB-231 cells. In Figures 4 and 7, the MEK/ERK inhibition test revealed that MEK/ERK inhibition induced cell death and suppressed the expression of CSC markers and the EMT phenotypes of both p-MDA-MB-231 cells and RT-R-MDA-MB-231 cells. This finding also suggested that ERK signaling is essential for the survival of MDA-MB-231 cells and that it may not be related to RT resistance per se. We also agree with the point. In addition, it was 
reported that other signaling pathways such as PI3K/Akt, and STAT or other anti-apoptotic proteins are important in the radio-resistance or radio-sensitivity of MDA-MB 231 cells (Table 2). However, there is some evidence to support that the ERK signaling is related to the RT-resistance of RT-R-MDA-MB-231 cells. Recent studies have depicted that the ERK1/2 activation prevails over the cell cycle arrest in the G2/M phase where cancer cells are susceptible to IR, thus inducing radio-resistance [5]. Another is that MDA-MB-231 cells are a triple-negative breast cancer cell line, which is known to have high CSC properties [49]. The third is that in our previous report, RT-R-MDA-MB-231 cells also showed an increased STAT 3 activity, which was reported to be related to cancer stemness and EMT, but that the inhibition of STAT 3 activity by the JNK inhibitor or Janus-activated kinase 2 (JAK2) inhibitor could not suppress the increased expression of CSC markers [50]. To solve this question, we carried out this study with antibody microarray analysis, which revealed that highly increased MAPK1 was enriched in all of the upregulated pathways of RT-RMDA-MB-231 cells (MAPK signaling, NOD-like receptor signaling, PI3K-Akt signaling, and Pathways in cancer). In addition, the KEGG pathway enrichment analysis showed that all enriched pathways include MAPK1, and the PPI network analysis of differentially expressed proteins showed that MAPK1 could be related to the resistance of cell death. The third is that the inhibition of ERK signaling reversed RT resistance (Figure 4). The inhibition of ERK signaling was reported to increase the anti-cancer efficacy of RT [51,52]. This finding could support the reversal of RT resistance caused by the inhibition of ERK signaling. With all of these findings, we can say that activated ERK signaling is one of the main mechanisms for the radio-resistance of MDA-MB-231 cells.

The second point to discuss would be the relationship between ERK signaling and EMT, as well as the CSC phenotype of RT-R-MDA-MB-231 cells, because it is mentioned that several other signaling pathways such as JAK/STAT, Hedgehog, Wnt, Notch, PI3K/PTEN, and nuclear factor- $\mathrm{KB}$ (NF- $\mathrm{kB}$ ) signaling pathways, compared to ERK signaling, are closely related to CSC properties [53-55], and the blocking of these pathways involved might be an effective way to target CSCs [55]. Even though it is not common, PRMT6-dependent CRAF/ERK signaling was reported to regulate CSC plasticity [56]. In addition, it was reported that the CSC properties-related signal is frequently complexed, and there is cross-talk between and among the mentioned various pathways [57]. In addition, the influence of ERK activity in regulating the CSC phenotype is also reported in gemcitabineresistant pancreatic cells [58], cisplatin-resistant non-small cell lung cancer cells [59], and docetaxel and carboplatin-resistant ovarian cancer cells [60]. To determine the real cause of the activated ERK signaling of RT-R-MDA-MB-231 cells, we performed whole genome sequencing. In the study, we could not find any mutations on the linear line for the activation of ERK signaling (data not shown), such as EGFR, SOS, B-raf, Ras, or MEK. Regarding this question, we could not give the audience clear evidence. Therefore, further studies are required.

The third point to discuss is why the phenotype of cell death induced by ERK inhibition differed between p-MDA-MB-231 cells and RT-R-MDA-MB-231 cells, while ERK inhibition induced cell death and suppressed the increased expression of CSC markers and the EMT phenotype of both p-MDA-MB-231 cells and RT-R-MDA-MB-231 cells. We speculate that the reason could be that RT-R-MDA-MB-231 cells exhibit a decreased activity of caspase. It has been reported that the cancer cells harboring caspase defects frequently undergo necroptosis or necrosis instead of apoptosis when the death signal appears [61]. Initially, we thought that the defects in caspase 3 activity were the main cause that was associated with increased ERK signaling, which was revealed by string analysis of the PPI network. By whole genome sequencing, we also found that RT-R-MDA-MB-231 cells harbor a nonsynonymous single nucleotide mutation in CASP9 (Arg173His; rs2308950), which is known to be involved in the pathogenesis of various cancers (data not shown) $[62,63]$. We speculate that this mutation is also responsible for RT-R-MDA-MB-231 cells undergoing necroptosis during the inhibition of ERK signaling. 
The fourth point to discuss would be the role of the other upregulated and downregulated proteins in RT-R-MDA-MB-231 cells. Although we could not discuss here all of the 26 proteins, recent studies have suggested that the inhibition of CLK1 also decreases cell proliferation [64]. CLK1 and FGF22 are oncogenes in cancer and their inhibition leads to the inhibition of breast cancer growth in cell culture and xenograft models $[65,66]$. This supports the possible contribution of upregulated CLK1 to the rapid growth of RT-R-MDAMB-231 cells. The most downregulated protein, caspase 3, may also contribute to the radio-resistance of RT-R-MDA-MB-231 cells, by avoiding IR-induced apoptosis [67]. All of these findings suggest that the changes in the expression of proteins may be involved in the biological phenotype of RT-R-MDA-MB-231 cells. Regarding these points, further studies are warranted.

The fifth point to discuss would be the mechanisms driving the upregulation of ERK signaling in RT-R-MDA-MB-231 cells. As we know that radiotherapy works by damaging the DNA of cancer cells, our first thought was that the upregulation of ERK signaling would be related to some of the mutations in the Ras-Raf-MEK-ERK pathway. Therefore, we performed whole genome sequencing, but there was no additional mutation of ERFR, PI3K/Akt, Ras, Raf, MEK, or ERK molecules of MDA-MB-231 cells (data not shown). In this paper, we inhibited ERK signaling with PD98059, a non-adenosine triphosphate competitive MAPK (MEK) inhibitor [68]. Therefore, we can speculate that the upregulation of ERK signaling would be caused by some hidden mutations in the upstream of the Ras-Raf-MEK-ERK pathway.

The weakness of this study is that we performed the experiment with only one cell line. It is in question whether the main mechanism of the radio-resistance of RT-R-MDA-MB-231 cells can be applied to all radiation-resistant breast cancer cell lines or can be generalized to triple-negative breast cancer cells. In addition, even regarding the radio-resistance of RT-R-MDA-MB 231 cells, other signaling pathways are also suggested as a key signaling pathway involved in the resistance. Similar to the signaling involved in CSC, the signaling involved in the radio-resistance of RT-R-MDA-MB 231 cells could also be complexed. However, aberrantly upregulated ERK signaling contributes to cancer cell proliferation, survival, and metastasis [14], and many other reports have suggested that ERK signaling is an important signaling pathway in radio-resistance $[5,15,52]$. Therefore, further research is also warranted regarding ERK signaling on the radio-resistance of breast cancer, especially on TNBC.

\section{Conclusions}

In summary, we found that ERK signaling was highly activated in RT-R-MDA-MB231 cells compared to p-MDA-MB-231 cells. The activated ERK signaling was associated with an increased cancer stemness and EMT phenotype. In addition, the RT resistance of RT-R-MDA-MB-231 cells was reversed by the inhibition of ERK signaling. Furthermore, the inhibition of ERK suppressed the CSC marker proteins. With all of these findings, we conclude that activated ERK signaling is one of the major hub signals related to the acquisition of radio-resistant MDA-MB-231 cells. This study suggests a distinct and advantageous therapeutic value of the targeting of the ERK signaling pathway in MDA-MB-231 cells. Further research is also warranted regarding ERK signaling on the radio-resistance of breast cancer, especially on TNBC.

Author Contributions: A.P. performed experiments and data analysis. E.J.J., S.-I.G., and W.S.L. performed data analysis. B.K.J., G.S.K., J.-M.J., S.C.H., and W.S.L. reviewed the manuscript and gave comments on the results. W.S.L. conceived of the hypothesis and directed the project. G.S.K. supported this project. A.P. and W.S.L. prepared the manuscript and confirmed the final manuscript. All authors have read and agreed to the published version of the manuscript.

Funding: This work was supported by the Basic Science Research Program through the National Research Foundation of Korea (NRF) funded by the Ministry of Education (2017R1D1A3B05030971).

Institutional Review Board Statement: Not applicable. 
Informed Consent Statement: Not applicable.

Data Availability Statement: Samples are not available from the authors.

Conflicts of Interest: The authors declare no conflict of interest.

\begin{tabular}{|c|c|}
\hline CSCs & Cancer stem cells \\
\hline СурА & Cyclophilin A \\
\hline AIF & Apoptosis-inducing factor \\
\hline EMT & Epithelial-to-mesenchymal transition \\
\hline ERK & Extracellular-signal-regulated kinase \\
\hline DDR & Damage response \\
\hline IR & Irradiation \\
\hline PI3K & Phosphatidylinositol 3-kinase \\
\hline MAPK & Mitogen-activated protein kinase \\
\hline Wnt & Wingless-related integration site \\
\hline GO & Gene Ontology \\
\hline KEGG & Kyoto Encyclopedia of Genes and Genomes \\
\hline STRING & Search Tool for the Retrieval of Interacting Genes \\
\hline DMSO & Dimethyl sulfoxide is an organosulfur \\
\hline MTT & 3-(4,5-dimethylthiazol-2-yl)-2,5-diphenyltetrazolium bromide \\
\hline PBS & Phosphate-buffered saline \\
\hline DAPI & $4^{\prime}, 6$-diamidino-2-phenylindole \\
\hline SDS-PAGE & Sodium dodecyl sulfate-polyacrylamide gel electrophoresis \\
\hline SDS & Sodium dodecyl sulphate \\
\hline RT & Radiotherapy \\
\hline RT-R & Radiotherapy-resistant \\
\hline SD & Standard deviation \\
\hline CLK1 & CDC-like kinases \\
\hline FGF22 & Fibroblast growth factor 22 \\
\hline F2R & Coagulation factor II (thrombin) receptor \\
\hline Gy & Gray \\
\hline CCD & Charge-coupled device \\
\hline JAK2 & Janus-activated kinase 2 \\
\hline PI3K-Akt & Phosphatidylinositol 3-kinase (PI3K)-protein kinase B (AKT) \\
\hline STAT & Signal transducer and activator of transcription \\
\hline NF- $k B$ & Nuclear factor- $\kappa \mathrm{B}$ \\
\hline EGFR & Epidermal growth factor receptor \\
\hline SOS & Son of Sevenless \\
\hline B-raf & B-Rapidly Accelerated Fibrosarcoma \\
\hline Ras & Rat sarcoma \\
\hline MEK & Mitogen-activated protein kinase kinase \\
\hline CASP9 & Caspase 9 \\
\hline IFIT2 & interferon-induced protein with tetratricopeptide repeats 2 \\
\hline TRIB3 & Tribbles homolog 3 \\
\hline ESM-1 & Endothelial cell-specific molecule-1 \\
\hline DLX2 & Vertebrate distal-less homeobox 2 \\
\hline
\end{tabular}

\section{References}

1. Siegel, R.L.; Miller, K.D.; Jemal, A. Cancer statistics, 2019. CA Cancer J. Clin. 2019, 69, 7-34. [CrossRef]

2. Griffiths, C.L.; Olin, J.L. Triple negative breast cancer: A brief review of its characteristics and treatment options. J. Pharm. Pract. 2012, 25, 319-323. [CrossRef]

3. $\quad$ Brownlee, Z.; Garg, R.; Listo, M.; Zavitsanos, P.; Wazer, D.E.; Huber, K.E. Late complications of radiation therapy for breast cancer: Evolution in techniques and risk over time. Gland Surg. 2018, 7, 371-378. [CrossRef] [PubMed]

4. Langlands, F.E.; Horgan, K.; Dodwell, D.D.; Smith, L. Breast cancer subtypes: Response to radiotherapy and potential radiosensitisation. Br. J. Radiol. 2013, 86, 20120601. [CrossRef] 
5. Marampon, F.; Ciccarelli, C.; Zani, B.M. Biological Rationale for Targeting MEK/ERK Pathways in Anti-Cancer Therapy and to Potentiate Tumour Responses to Radiation. Int. J. Mol. Sci. 2019, 20, 2530. [CrossRef]

6. Luo, M.; Ding, L.; Li, Q.; Yao, H. miR-668 enhances the radioresistance of human breast cancer cell by targeting IkB $\alpha$. Breast Cancer 2017, 24, 673-682. [CrossRef] [PubMed]

7. Huang, M.; Wei, H.; Ling, R.; Lv, Y. Opposite effects of TNF- $\alpha$ on proliferation via ceramide in MDA-MB-231 and MCF-7 breast cancer cell lines. Int. J. Clin. Exp. Med. 2018, 11, 9239-9247.

8. Ko, Y.S.; Jin, H.; Lee, J.S.; Park, S.W.; Chang, K.C.; Kang, K.M.; Jeong, B.K.; Kim, H.J. Radioresistant breast cancer cells exhibit increased resistance to chemotherapy and enhanced invasive properties due to cancer stem cells. Oncol. Rep. 2018, 40, 3752-3762. [CrossRef]

9. Kopf, E.; Zharhary, D. Antibody arrays-An emerging tool in cancer proteomics. Int. J. Biochem. Cell Biol. 2007, 39, 1305-1317. [CrossRef]

10. Bernichon, E.; Vallard, A.; Wang, Q.; Attignon, V.; Pissaloux, D.; Bachelot, T.; Heudel, P.E.; Ray-Coquard, I.; Bonnet, E.; de la Fouchardière, A.; et al. Genomic alterations and radioresistance in breast cancer: An analysis of the ProfiLER protocol. Ann. Oncol. 2017, 28, 2773-2779. [CrossRef] [PubMed]

11. Strasser-Wozak, E.M.; Hartmann, B.L.; Geley, S.; Sgonc, R.; Böck, G.; Santos, A.J.; Hattmannstorfer, R.; Wolf, H.; Pavelka, M.; Kofler, R. Irradiation induces G2/M cell cycle arrest and apoptosis in p53-deficient lymphoblastic leukemia cells without affecting Bcl-2 and Bax expression. Cell Death Differ. 1998, 5, 687-693. [CrossRef] [PubMed]

12. Bernhard, E.J.; Maity, A.; Muschel, R.J.; McKenna, W.G. Effects of ionizing radiation on cell cycle progression. Radiat. Environ. Biophys. 1995, 34, 79-83. [CrossRef]

13. Pawlik, T.M.; Keyomarsi, K. Role of cell cycle in mediating sensitivity to radiotherapy. Int. J. Radiat. Oncol. Biol. Phys. 2004, 59, 928-942. [CrossRef] [PubMed]

14. Meier, K.E.; Gause, K.C.; Wisehart-Johnson, A.E.; Gore, A.C.S.; Finley, E.L.; Jones, L.G.; Bradshaw, C.D.; McNair, A.F.; Ella, K.M. Effects of Propranolol on Phosphatidate Phosphohydrolase and Mitogen-Activated Protein Kinase Activities in A7r5 Vascular Smooth Muscle Cells. Cell. Signal. 1998, 10, 415-426. [CrossRef]

15. Munshi, A.; Ramesh, R. Mitogen-activated protein kinases and their role in radiation response. Genes Cancer 2013, 4, 401-408. [CrossRef]

16. Dudley, D.T.; Pang, L.; Decker, S.J.; Bridges, A.J.; Saltiel, A.R. A synthetic inhibitor of the mitogen-activated protein kinase cascade. Proc. Natl. Acad. Sci. USA 1995, 92, 7686. [CrossRef]

17. Favata, M.F.; Horiuchi, K.Y.; Manos, E.J.; Daulerio, A.J.; Stradley, D.A.; Feeser, W.S.; Van Dyk, D.E.; Pitts, W.J.; Earl, R.A.; Hobbs, F.; et al. Identification of a Novel Inhibitor of Mitogen-activated Protein Kinase Kinase. J. Biol. Chem. 1998, 273, 18623-18632. [CrossRef] [PubMed]

18. Sebolt-Leopold, J.S.; Dudley, D.T.; Herrera, R.; Becelaere, K.V.; Wiland, A.; Gowan, R.C.; Tecle, H.; Barrett, S.D.; Bridges, A.; Przybranowski, S.; et al. Blockade of the MAP kinase pathway suppresses growth of colon tumors in vivo. Nat. Med. 1999, 5, 810. [CrossRef]

19. Marampon, F.; Gravina, G.L.; Di Rocco, A.; Bonfili, P.; Di Staso, M.; Fardella, C.; Polidoro, L.; Ciccarelli, C.; Festuccia, C.; Popov, V.M.; et al. MEK/ERK inhibitor U0126 increases the radiosensitivity of rhabdomyosarcoma cells in vitro and in vivo by downregulating growth and DNA repair signals. Mol. Cancer Ther. 2011, 10, 159-168. [CrossRef] [PubMed]

20. Santos, N.F.D.; Silva, R.F.; Pinto, M.M.; Silva, E.B.; Tasat, D.R.; Amaral, A. Active caspase-3 expression levels as bioindicator of individual radiosensitivity. An. Acad. Bras. Cienc. 2017, 89, 649-659. [CrossRef]

21. Samudio, I.; Konopleva, M.; Hail, N., Jr.; Shi, Y.-X.; McQueen, T.; Hsu, T.; Evans, R.; Honda, T.; Gribble, G.W.; Sporn, M.; et al. 2-Cyano-3,12-dioxooleana-1,9-dien-28-imidazolide (CDDO-Im) Directly Targets Mitochondrial Glutathione to Induce Apoptosis in Pancreatic Cancer. J. Biol. Chem. 2005, 280, 36273-36282. [CrossRef]

22. Christofferson, D.E.; Yuan, J. Cyclophilin A release as a biomarker of necrotic cell death. Cell Death Differ. 2010, 17, 1942-1943. [CrossRef]

23. Shepard, D.M.; Ferris, M.C.; Olivera, G.H.; Mackie, T.R. Optimizing the Delivery of Radiation Therapy to Cancer Patients. SIAM Rev. 1999, 41, 721-744. [CrossRef]

24. Cannan, W.J.; Pederson, D.S. Mechanisms and Consequences of Double-Strand DNA Break Formation in Chromatin. J.Cell. Physiol. 2016, 231, 3-14. [CrossRef]

25. Schulz, A.; Meyer, F.; Dubrovska, A. Cancer Stem Cells and Radioresistance: DNA Repair and Beyond. Cancers 2019, 11, 862. [CrossRef]

26. Gray, M.; Turnbull, A.K.; Ward, C.; Meehan, J.; Martínez-Pérez, C.; Bonello, M.; Pang, L.Y.; Langdon, S.P.; Kunkler, I.H.; Murray, A.; et al. Development and characterisation of acquired radioresistant breast cancer cell lines. Radiat. Oncol. 2019, 14, 64. [CrossRef] [PubMed]

27. Ediriweera, M.K.; Moon, J.Y.; Nguyen, Y.T.; Cho, S.K. 10-Gingerol Targets Lipid Rafts Associated PI3K/Akt Signaling in Radio-Resistant Triple Negative Breast Cancer Cells. Molecules 2020, 25, 3164. [CrossRef]

28. Jin, H.; Rugira, T.; Ko, Y.S.; Park, S.W. ESM-1 Overexpression is Involved in Increased Tumorigenesis of Radiotherapy-Resistant Breast Cancer Cells. Cancers 2020, 12, 1363. [CrossRef] 
29. Lu, L.; Dong, J.; Wang, L.; Xia, Q.; Zhang, D.; Kim, H.; Yin, T.; Fan, S.; Shen, Q. Activation of STAT3 and Bcl-2 and reduction of reactive oxygen species (ROS) promote radioresistance in breast cancer and overcome of radioresistance with niclosamide. Oncogene 2018, 37, 5292-5304. [CrossRef]

30. Bravatà, V.; Cammarata, F.P.; Minafra, L.; Musso, R.; Pucci, G.; Spada, M.; Fazio, I.; Russo, G.; Forte, G.I. Gene Expression Profiles Induced by High-dose Ionizing Radiation in MDA-MB-231 Triple-negative Breast Cancer Cell Line. Cancer Genom. Proteom. 2019, 16, 257-266. [CrossRef] [PubMed]

31. Choi, Y.J.; Baek, G.Y.; Park, H.R.; Jo, S.K.; Jung, U. Smad2/3-Regulated Expression of DLX2 Is Associated with Radiation-Induced Epithelial-Mesenchymal Transition and Radioresistance of A549 and MDA-MB-231 Human Cancer Cell Lines. PLoS ONE 2016, 11, e0147343. [CrossRef]

32. Yin, L.; Gao, Y.; Zhang, X.; Wang, J.; Ding, D.; Zhang, Y.; Zhang, J.; Chen, H. Niclosamide sensitizes triple-negative breast cancer cells to ionizing radiation in association with the inhibition of Wnt/ $\beta$-catenin signaling. Oncotarget 2016, 7, 42126-42138. [CrossRef]

33. Lin, F.; Luo, J.; Gao, W.; Wu, J.; Shao, Z.; Wang, Z.; Meng, J.; Ou, Z.; Yang, G. COX-2 promotes breast cancer cell radioresistance via p38/MAPK-mediated cellular anti-apoptosis and invasiveness. Tumour Biol. J. Int. Soc. Oncodev. Biol. Med. 2013, 34, $2817-2826$. [CrossRef] [PubMed]

34. Koh, S.Y.; Moon, J.Y.; Unno, T. Baicalein Suppresses Stem Cell-Like Characteristics in Radio- and Chemoresistant MDA-MB-231 Human Breast Cancer Cells through Up-Regulation of IFIT2. Nutrients 2019, 11, 624. [CrossRef]

35. Lammering, G.; Valerie, K.; Lin, P.S.; Hewit, T.H.; Schmidt-Ullrich, R.K. Radiation-induced activation of a common variant of EGFR confers enhanced radioresistance. Radiother. Oncol. J. Eur. Soc. Ther. Radiol. Oncol. 2004, 72, 267-273. [CrossRef] [PubMed]

36. Kim, M.H.; Jung, S.Y.; Ahn, J.; Hwang, S.G.; Woo, H.J.; An, S.; Nam, S.Y.; Lim, D.S.; Song, J.Y. Quantitative proteomic analysis of single or fractionated radiation-induced proteins in human breast cancer MDA-MB-231 cells. Cell Biosci. 2015, 5, 2. [CrossRef] [PubMed]

37. Miao, W.; Fan, M.; Huang, M.; Li, J.J.; Wang, Y. Targeted Profiling of Heat Shock Proteome in Radioresistant Breast Cancer Cells. Chem. Res. Toxicol. 2019, 32, 326-332. [CrossRef]

38. Lee, Y.C.; Wang, W.L.; Chang, W.C.; Huang, Y.H.; Hong, G.C.; Wang, H.L.; Chou, Y.H. Tribbles Homolog 3 Involved in Radiation Response of Triple Negative Breast Cancer Cells by Regulating Notch1 Activation. Cancers 2019, 11, 127. [CrossRef]

39. Hou, J.; Li, L.; Zhu, H.; Chen, H.; Wei, N.; Dai, M.; Ni, Q.; Guo, X. Association between breast cancer cell migration and radiosensitivity in vitro. Oncol. Lett. 2019, 18, 6877-6884. [CrossRef] [PubMed]

40. Yang, B.; Kuai, F.; Chen, Z.; Fu, D.; Liu, J.; Wu, Y.; Zhong, J. miR-634 Decreases the Radioresistance of Human Breast Cancer Cells by Targeting STAT3. Cancer Biother. Radiopharm. 2020, 35, 241-248. [CrossRef]

41. Li, J.Y.; Li, Y.Y.; Jin, W.; Yang, Q.; Shao, Z.M.; Tian, X.S. ABT-737 reverses the acquired radioresistance of breast cancer cells by targeting Bcl-2 and Bcl-xL. J. Exp. Clin. Cancer Res. 2012, 31, 102. [CrossRef]

42. Nguyen, Y.T.; Moon, J.Y.; Ediriweera, M.K.; Cho, S.K. Phenethyl Isothiocyanate Suppresses Stemness in the Chemo- and RadioResistant Triple-Negative Breast Cancer Cell Line MDA-MB-231/IR Via Downregulation of Metadherin. Cancers 2020, 12, 268. [CrossRef] [PubMed]

43. Oommen, D.; Prise, K.M. KNK437, abrogates hypoxia-induced radioresistance by dual targeting of the AKT and HIF- $1 \alpha$ survival pathways. Biochem. Biophys. Res. Commun. 2012, 421, 538-543. [CrossRef]

44. Kuger, S.; Cörek, E.; Polat, B.; Kämmerer, U.; Flentje, M.; Djuzenova, C.S. Novel PI3K and mTOR Inhibitor NVP-BEZ235 Radiosensitizes Breast Cancer Cell Lines under Normoxic and Hypoxic Conditions. Breast Cancer Basic Clin. Res. 2014, 8, 39-49. [CrossRef] [PubMed]

45. Holler, M.; Grottke, A.; Mueck, K.; Manes, J.; Jücker, M.; Rodemann, H.P.; Toulany, M. Dual Targeting of Akt and mTORC1 Impairs Repair of DNA Double-Strand Breaks and Increases Radiation Sensitivity of Human Tumor Cells. PLoS ONE 2016, 11, e0154745. [CrossRef]

46. Chen, X.; Ma, N.; Zhou, Z.; Wang, Z.; Hu, Q.; Luo, J.; Mei, X.; Yang, Z.; Zhang, L.; Wang, X.; et al. Estrogen Receptor Mediates the Radiosensitivity of Triple-Negative Breast Cancer Cells. Med Sci. Monit. Int. Med J. Exp. Clin. Res. 2017, 23, 2674-2683. [CrossRef]

47. Liu, B.; Han, D.; Zhang, T.; Cheng, G.; Lu, Y.; Wang, J.; Zhao, H.; Zhao, Z. Hypoxia-induced autophagy promotes EGFR loss in specific cell contexts, which leads to cell death and enhanced radiosensitivity. Int. J. Biochem. Cell. Biol. 2019, 111, 12-18. [CrossRef]

48. Arnold, K.M.; Opdenaker, L.M.; Flynn, N.J.; Appeah, D.K.; Sims-Mourtada, J. Radiation induces an inflammatory response that results in STAT3-dependent changes in cellular plasticity and radioresistance of breast cancer stem-like cells. Int. J. Radiat. Biol. 2020, 96, 434-447. [CrossRef] [PubMed]

49. Park, S.Y.; Choi, J.H.; Nam, J.S. Targeting Cancer Stem Cells in Triple-Negative Breast Cancer. Cancers 2019, 11, 965. [CrossRef]

50. Ko, Y.S.; Jung, E.J.; Go, S.-I.; Jeong, B.K.; Kim, G.S.; Jung, J.-M.; Hong, S.C.; Kim, C.W.; Kim, H.J.; Lee, W.S. Polyphenols Extracted from Artemisia annua L. Exhibit Anti-Cancer Effects on Radio-Resistant MDA-MB-231 Human Breast Cancer Cells by Suppressing Stem Cell Phenotype, $\beta$-Catenin, and MMP-9. Molecules 2020, 25, 1916. [CrossRef]

51. Qin, J.; Xin, H.; Nickoloff, B.J. Specifically targeting ERK1 or ERK2 kills melanoma cells. J. Transl. Med. 2012, 10, 15. [CrossRef]

52. Ciccarelli, C.; Di Rocco, A.; Gravina, G.L.; Mauro, A.; Festuccia, C.; Del Fattore, A.; Berardinelli, P.; De Felice, F.; Musio, D.; Bouché, M.; et al. Disruption of MEK/ERK/c-Myc signaling radiosensitizes prostate cancer cells in vitro and in vivo. J. Cancer Res. Clin. Oncol. 2018, 144, 1685-1699. [CrossRef] [PubMed] 
53. Matsui, W.H. Cancer stem cell signaling pathways. Medicine 2016, 95, S8-S19. [CrossRef]

54. Tuasha, N.; Petros, B. Heterogeneity of Tumors in Breast Cancer: Implications and Prospects for Prognosis and Therapeutics. Scientifica 2020, 2020, 4736091. [CrossRef] [PubMed]

55. Moncharmont, C.; Levy, A.; Gilormini, M.; Bertrand, G.; Chargari, C.; Alphonse, G.; Ardail, D.; Rodriguez-Lafrasse, C.; Magné, N. Targeting a cornerstone of radiation resistance: Cancer stem cell. Cancer Lett. 2012, 322, 139-147. [CrossRef] [PubMed]

56. Chan, L.H.; Zhou, L.; Ng, K.Y.; Wong, T.L.; Lee, T.K.; Sharma, R.; Loong, J.H.; Ching, Y.P.; Yuan, Y.-F.; Xie, D.; et al. PRMT6 Regulates RAS/RAF Binding and MEK/ERK-Mediated Cancer Stemness Activities in Hepatocellular Carcinoma through CRAF Methylation. Cell Rep. 2018, 25, 690-701. [CrossRef]

57. Skvortsov, S.; Debbage, P.; Lukas, P.; Skvortsova, I. Crosstalk between DNA repair and cancer stem cell (CSC) associated intracellular pathways. Semin. Cancer Biol. 2015, 31, 36-42. [CrossRef] [PubMed]

58. Chai, X.; Chu, H.; Yang, X.; Meng, Y.; Shi, P.; Gou, S. Metformin Increases Sensitivity of Pancreatic Cancer Cells to Gemcitabine by Reducing CD133+ Cell Populations and Suppressing ERK/P70S6K Signaling. Sci. Rep. 2015, 5, 14404. [CrossRef]

59. Chen, M.-J.; Wu, D.-W.; Wang, Y.-C.; Chen, C.-Y.; Lee, H. PAK1 confers chemoresistance and poor outcome in non-small cell lung cancer via $\beta$-catenin-mediated stemness. Sci. Rep. 2016, 6, 34933. [CrossRef]

60. Tung, S.L.; Huang, W.C.; Hsu, F.C.; Yang, Z.P.; Jang, T.H.; Chang, J.W.; Chuang, C.M.; Lai, C.R.; Wang, L.H. miRNA-34c-5p inhibits amphiregulin-induced ovarian cancer stemness and drug resistance via downregulation of the AREG-EGFR-ERK pathway. Oncogenesis 2017, 6, e326. [CrossRef]

61. Su, Z.; Yang, Z.; Xie, L.; DeWitt, J.P.; Chen, Y. Cancer therapy in the necroptosis era. Cell Death Differ. 2016, 23, 748-756. [CrossRef]

62. Azevedo, A.P.; Silva, S.N.; Reichert, A.; Lima, F.; Júnior, E.; Rueff, J. Effects of polymorphic DNA genes involved in BER and caspase pathways on the clinical outcome of myeloproliferative neoplasms under treatment with hydroxyurea. Mol. Med. Rep. 2018, 18, 5243-5255. [CrossRef] [PubMed]

63. Zhang, Z.Y.; Xuan, Y.; Jin, X.Y.; Tian, X.; Wu, R. CASP-9 gene functional polymorphisms and cancer risk: A large-scale association study plus meta-analysis. Genet. Mol. Res. GMR 2013, 12, 3070-3078. [CrossRef]

64. Araki, S.; Dairiki, R.; Nakayama, Y.; Murai, A.; Miyashita, R.; Iwatani, M.; Nomura, T.; Nakanishi, O. Inhibitors of CLK protein kinases suppress cell growth and induce apoptosis by modulating pre-mRNA splicing. PLoS ONE 2015, 10, e0116929. [CrossRef] [PubMed]

65. Yoshida, T.; Kim, J.H.; Carver, K.; Su, Y.; Weremowicz, S.; Mulvey, L.; Yamamoto, S.; Brennan, C.; Mei, S.; Long, H.; et al. CLK2 Is an Oncogenic Kinase and Splicing Regulator in Breast Cancer. Cancer Res. 2015, 75, 1516-1526. [CrossRef] [PubMed]

66. Katoh, M. FGFR inhibitors: Effects on cancer cells, tumor microenvironment and whole-body homeostasis (Review). Int. J. Mol. Med. 2016, 38, 3-15. [CrossRef] [PubMed]

67. Rahmanian, N.; Hosseinimehr, S.J.; Khalaj, A. The paradox role of caspase cascade in ionizing radiation therapy. J. Biomed. Sci. 2016, 23, 88. [CrossRef]

68. Wu, P.K.; Park, J.I. MEK1/2 Inhibitors: Molecular Activity and Resistance Mechanisms. Semin. Oncol. 2015, 42, 849-862. [CrossRef] 